\title{
Japan's Rejuvenation: Origins, Debates and Concepts
}

It is said that heaven does not create one man above or below another man. Any existing distinction between the wise and the stupid, between the rich and the poor, comes down to a matter of education.

Gakumon no Susume [An Encouragement of Learning] (1872-1876)

Once the wind of Western civilization blows to the East, every blade of grass and every tree in the East follow what the Western wind brings... We do not have time to wait for the enlightenment of our neighbors so that we can work together toward the development of Asia. It is better for us to leave the ranks of Asian nations and cast our lot with civilized nations of the West... We should deal with them exactly as the Westerners do.

"Datsu-a-ron" [On departure from Asia], Jiji Shimpo (1885-03-16).

Fukuzawa Yukichi (福澤 諭吉) 


\section{Japan's Political and Philosophical Traditions: Equality, Hierarchy and Exceptionalism}

\section{The China Dilemma}

Widely regarded as one of the founders of modern Japan, Fukuzawa Yukichi's (福澤 諭吉) thinking and philosophy register the angst of the dilemmas that contemporary Japan faces today (Fukuzawa 1875, 2007). Fukuzawa, born into a Samurai class was an opponent of elitism and feudal thinking, particularly disliked the ideas of Confucian hierarchy that pervaded Japan. His disdain for the way Japanese politics, steeped in traditional order where many leading Samurais were not responding to economic decay and social ills of the day was only matched by his disappointment in Japan's inability to deal with the challenge of Western infringement and colonialism. As part of Japan's first embassy to the United States, he travelled widely in not only the United States but also to Europe, where he absorbed, crystallized and translated his thinking into guiding principles for Japanese politics.

The roots of Japanese enlightenment during the Meiji Restoration stemmed from Japanese reforms privileging equality over hierarchy and choosing self-determination over divine destiny. Capitalizing on Westphalian ideals, the Meiji elites saw the future of the Japanese nation emerging as a modern sovereign state in the fraternity of Western colonial powers. Japan's destiny lied in casting off the constraining shackles of her feudal Confucian past and the embracement of the prevailing imperialistic logic then. Fukuzawa's famous thesis "only when the individual is independent can the nation of such individuals be independent (一身独立して 一國独立する/ isshin dokuritsu shite ikkoku dokuritsu suru) could be loosely transposed to Japan's understanding of how international politics worked. Needless to say, the illusion that the Westphalian international system where nation-states are equal (in principle at least), and in their relations independent (in principle at least) was hardly the international system Japan and her East Asian neighbors found themselves being transposed into as they entered the twentieth century.

Fukuzawa's enlightenment ideas are not new. For centuries, Japanese intellectuals have struggled with ideals imposed by Chinese inspired Confucianism (Watanabe 2012). The influence of Confucianism in Japan has been widespread, but over the course of time, Japanese thinkers and philosophers debated the virtues of their national development vis-à-vis the developments of their closest neighbor in the continent. China figures 
prominently in ancient and contemporary Japanese political philosophy and thinking for two natural reasons. First, until the arrival of the West via colonialism and modern technology to Asia, and for that matter, Japan did not come into contact with a credible alternative set of philosophy, thinking and social system. The primary reference for East Asian societies including Japan remained China and Chinese civilization. Second, by this time, the influence of the Chinese Confucian thinking has over the course of centuries permeated into the way how other East Asian societies structured themselves and conducted their daily affairs. The Confucian model in short informed the basic infrastructure of their society and provided the basis for these societies to debate about the merits or demerits of what worked and what did not for their society and the differentials in development trajectory as well as strategies for their future.

One natural but key development in Chinese and Japanese society is the development of the Samurai class in Japan. Feudal Chinese society has always been divided into four classes: Confucian literati and landlords, peasants, artisans, and merchants. Japanese society mirrors this stratificationwith one important exception. Samurai warriors, not Confucian literati and landowners, stands at the Apex of this stratification. This social structure has largely been in force since the twelfth century, with the Emperor revered as the sovereign. Viewed from today's prism, this might seem ironic, but premodern Japan is very much a warrior nation, setting herself apart from China in this respect. This is exemplified by the Japanese idiom, "Cherry blossom stands out amongst flowers, and the warrior stands out amongst men” (花は桜木人は武士; Hana wa sakuragi, hito wa bushi). This contrasts against the Chinese idiom that states good quality men will never be soldiers just like good quality metal would not be cast into nails (好男不当兵,好铁 不打钉, Haonan budang Bing, Hao tie bu dading). This idiom of course is not representative of Chinese attitudes on military force throughout Chinese history. The Chinese version of medieval pacifism was prevalent during Song dynasty (960-1279) as Chinese civilizational attainment and economic prosperity reached a peak, and also in later Ming dynasty (1368-1644). Tang China (618-906 A.D.) and Han dynasty (206 B.C.-220 A.D.) was more militaristic due to government structure and the way the military was raised and incorporated.

Many members of Japanese warrior class therefore did not think that Confucian learning could or would be able to help Japan resolve their existing social and political problems. The conceptualization of Japan as a nation to compete with China led many to move towards "National Learning" (Kokugaku) with an emphasis on the martial arts element. 
Our nation is a nation of arms. The land to the West [China] is a nation of letters. Nations of letters value the pen. Nation of arms value the sword. That's the way it has been from the beginning ... Our country and theirs are separated from one another by hundreds of miles, our customs are completely different, the temperaments of our people are dissimilar - so how could we possibly share the same Way? (Nakamura 1843 cited in Watanabe 2012: 285)

The question of what is a viable strategy for Japan for the future and how this relates to China has been a central question for Japanese elites since the sixteenth century. China became the primary reference to compare and contrast, to emulate and distinguish (but eventually to discard during the Meiji era). Japanese exceptionalism therefore has its roots from this period onwards. During the eighteenth century, Japanese scholars ruminated about the peace and relative prosperity of Tokugawa Japan in comparison to continental China (Maruyama 1975) and the Warring States (Sengoku period 1467-1586) of the past. Matsuzaki Kankai (1725-75) suggests that compared to the Xia and Zhou dynasties, the great peace Japan enjoys far surpasses China (Watanabe 2012: 186-187).

Ota Kinko, suggested in that in [Hogen Monogatari], Japan's reign of twenty-seven emperors in a period of at least 340 years did not see a single official put to death. This model of benevolent government was one that dynasties of the Tang, Song and Ming could not hope to emulate, arguing this is not something that "even the rule of the sages of the Three Dynasties could not be better .... thus our country is more easily governed than China, whether under centralized rule or under feudal rule".

Another noted scholar, Hattori Nankaku, a contemporary of Ota Kinko suggests that this could be due to the superior nature of the Japanese people:

In China, sages and emperors stand below their deified ancestors, while the various lords arrayed throughout the land acknowledge the emperor, and then below them there are a bunch of dukes and such ... it is enough to make you think that the character of the people of that country is really quite awful. And this is why the sages ruled through rites and music. But in Japan it appears peaceful rule can be effected without rites and music, so the character of our people must be better than that of the Chinese (Nankaku in Yuasa 1993 cited by Watanabe 2012: 188)

Japanese thinkers suggest Japan is superior to China because of the Japanese allegiance to the traits of honesty and faithfulness (Ota 1823 cited in Watanabe 2012: 188). Japanese people were seen as more 
substantial and less deceitful, and truly blessed by divine powers among early Japanese thinkers (Watanabe 2012: 283-291).

Second, this illustrated the reverence that both Japanese sovereign and subjects had for each other. Motoori Norinaga (born 1730) a prominent political thinker in the eighteenth century employed by the Tokugawa House in Wakayama, argued Japan's long peace was a result of this relationship, and it helped Japan avoid the turmoil and difficulties experienced in China. Norinaga believed in universal truths, and argued against relativism-that peoples of their land should only believe in the myths of their land for this would result in people only believing in fiction (political myths). Therefore, Norinaga argues that the peace that prevailed in Japan was possible because of the deep respect that the subjects had for the sovereign, and Japanese subject would never think of overthrowing the sovereign as to replace them. In the context of pre-modern Japan, the concept of Government (matsurigoto 政), is a "service rendered to the sovereign by the subjects" (Watanabe 2012: 244). Therefore "whether a country was well governed depends on whether inferiors respect superiors. If the members of the ruling class show deep respect for superiors, the lower classes in turn will show similar respect for those above them, and the country will naturally be well governed" (Brownlee 1988: 56 cited in Watanabe 2012: 244). This thinking is similar in logic to the Confucian ideals of "Five Cardinal Relationships" (五倫 or Wu Lun) where political and social cosmology consists of five principal type of relationships: between rulers and subjects; parents and offspring; husband and wife; among siblings and among friends. These relationships are defined in terms of a set obligations that each party should carry out in order for the cosmological universe to function properly.

Unlike in China, subjects in Japan would unlikely think of overthrowing their sovereign and assuming the Emperor position for herself, and thus Japanese exceptionalism lies in the unquestioning loyalty of the subjects to the sovereign. The importance of the continuity of Japan's imperial lineage thus becomes the ground for asserting Japan's superiority over China and Korea. China was often referred to disparagingly as Seido (land to the West), Seiju (western barbarians), Shin'i (Qing Barbarians) or Shina (China) (Watanabe 2012: 289). By the Edo period, Japan was so decentralized with nearly 300 fiefdoms, it was therefore a wonder that such a decentralized system was able to enjoy the long period of stability. 


\section{Japan's Exceptionalism}

Japanese exceptionalism therefore is premised upon the rejection that China should be construed as the Middle Kingdom. Some early Japanese thinkers considered that Japan herself could be construed as the Middle Kingdom as well. From the mid-fifteenth century onwards, Japan sought to improve upon their conditions through both adapting to Chinese institutions and indigenizing the practices to suit their circumstances. The question of national development and social learning is therefore critical. Japanese intellectuals of modern times acknowledged the centrality of Chinese contributions but premised Japanese exceptionalism on Japan's ability to mount a challenge to the China model that could therefore be made on improving existing innovations made in China (Katsube 1785 cited in Watanabe 2012: 282). In this sense, there is every confidence that adapting innovations and intellectual advancements to indigenous conditions is key to reconciling domestic needs and Japan's place in the wider world.

Within Japan, the reverence of the institution of the Emperor thus became the pride and the foci for the elites to show both the equality of Japan vis-à-vis China, and to offer a competing universe and frame of reference for the Japanese worldview. This was critical for Japan's subsequent empire building efforts. The Japanese court, like the Chinese, instituted a parallel system of tributary-vassal relations. The Kingdom of Ryukyu (present day Okinawa), situated between China and Japan consequently had to present tribute to both the Chinese Court (from Ming China in 1372), the Satsuma Daimyo (from 1590 onwards) and subsequently to the Japanese Emperor when Japan was unified (Leung 1978: 7-24). The Satsuma Daimyo had incorporated Ryukyu ostensibly because they did not help them in their War against Korea, but more so because the Satsuma Daimyo wanted to strengthen against their domestic rivals and share in the Ryukyu trade with Southeast Asia and China.

This ability to learn from the existing hegemon, and at the same time resist her influence is a signature hallmark of Japan exceptionalism in premodern East Asia (Paine 2017). This duality underpins Japan's thinking in pre-modern era vis-à-vis China, at the beginning of the twentieth century vis-à-vis Britain and in the postwar era with the United States. Japan would not accept another power's presumed superiority-particularly when the power is the hegemon of the day. This is the basis of Japan's quest for equality. The "peripheral" and isolated nature of Japan's 
geography help with the notion of the centrality of Japan too exemplified by the letter Prince Shotoku (Asuka period) wrote to Emperor of Sui in 607 referring to himself as the "Son of Heaven" in the "Land of the rising Sun".

Another important attribute that made Japan exceptional was her capacity to learn and adopt from stronger nations, particularly existing hegemon to adapt the institutions that would help strengthen her power vis-à-vis her external foes and friends. Thus, for Meiji thinkers such as Fukuzawa, Japanese exceptionalism expressed in terms of progress achieved through a complete and thorough learning and adaptation of Western methods, philosophy and thinking. Western learning is more practical compared to traditional Chinese way, and in essence, critical for Japan because Western knowledge provides an alternative basis for Japanese society to utilize in its everyday application. The value was not in the things or knowledge acquired, but how they were used (Blacker 1964: 63). Therefore, there was no contradiction for Meiji elites in Japan's quest for exceptionalism in International Relations and egalitarianism in domestic politics. Meiji and Taisho elites did not see a contradiction in adopting and learning from the West and at the same time resisting the Western colonial powers which brought ships or guns.

The concern for egalitarianism i.e. the idea not to be seen as a "secondary" power, pushed Japan in earlier centuries to grow her domestic institutions while active debates on the nature of Confucianism was seen again in this era. Intellectuals, such as Fukuzawa, changed their perceptions over time over the question of equality and egalitarianism between individuals in society and nations. In the initial years, he felt Japan should open up not due to fear of the Western colonization, but because he felt Japan has a sense of moral duty and self-interest as nations have equal rights. Japan was fascinated by the development of international legal jurisprudence, (萬國公法) in the late Edo period onwards. The solution to prevent the colonization of Japan and to ward off the attempts to colonize Japan was for Japan to learn from the West. In his later years, he became particularly worried about the prospects of how Japan can withstand colonization, particularly in her intercourse with the West.

Thus, the problems that the Meiji elites faced were not so different from their predecessors in the era before. In undertaking reforms to open up and learn from the West, the elites at this juncture came face to face with the difficult question of how Japan could strive for and maintain her independence whilst learning from the dominant hegemon at hand. 
As the external environment was changing rapidly, particularly in East Asia, the Meiji elites felt even more compelled to ensure that even as Japan strove for her best during this era, Japan needed to remain free and independent.

By 1878, Fukuzawa was disillusioned as he believed that international relations were not governed by reason but by the principle of strong devouring the weak (jakuniku-kyoshoku) (Blacker 1964: 172). Japan had to seek Civilization, not only through the perfection of human condition domestically through new learning and adaptation to allow this enlightenment but also ensure that it survived the Hobbesian International Political system (Fukuzawa 1875 [2008 Retranslation]: 225-260). Neither divinely-bestowed legitimacy nor Confucian ideals of hierarchy translate into power in international politics. Realpolitik indicators such as military attributes, state coffers, and political-economic influence mattered much more. In short, liberalism was insufficient alone to guarantee Japan's wellbeing, rather it had to be enforced with realpolitik calculations. It is not surprising therefore to find Japan once again evolved to change their national character-to quickly assume, adapt and innovate various elements of their society to become a first rate colonial power-the prevalent ideology at a time of European expansionism in order to maintain a sense of egalitarianism with them, and at the same time learn from these countries to further enhance Japan.

At the turn of the nineteenth century, Japan did indeed learn and adopt the ways of foreign adversaries in earnest (Samuels 1994). The British were invited by the Japanese during this era to assist in the construction of Japan's transportation system (hence the Japanese drive on the left like the British rather than the Americans). Japanese elites learn the wonders of modern steam-engine and ship building technology from the Americans and Britain (which they later used to assemble one of the largest naval armada for the Second World War). Drawing from the Prussian and British models, Meiji elites wrote the Meiji Constitution (明治憲法). Tokyo learnt the principles of Constitutional monarchy and sent delegations of students and officials to Europe and America. During Taisho period, Japan boldly emulated the institutions of liberal democracy even though to a large extent, it was questionable if the Japanese people then had truly embraced the spirit of liberalism and democracy at home.

True to Japan's national character, the nation did extremely well not only to reform her domestic structures but also were able to calibrate and craft her external policies effectively, positioning Japan to do extremely 
well in the age of imperialism. Beginning with a victory in the 1895 SinoJapanese War and the 1905 Russo-Japanese War, Japan achieved strategic pre-eminence that was absolutely necessary to her aspirations to be "equal" to the Western powers in the region. Ironically, in her quest to achieve parity with the colonial powers, Tokyo subordinated the rest of Asian neighbors to her imperialistic ambitions.

Japan did earn a seat among the Western powers but not earn the commensurate respect and power Tokyo craved. International reactions to the 21 Demands levied upon China in 1915, the limitations imposed by the Washington Naval Treaty in 1922 and the enactment of the Japan Exclusion Act in the United States were interpreted negatively by Japan as both a security problem, and also a racial discrimination one. Thus, despite decades in learning, adapting and applying, Japan did not secure the requisite respect and security she sought. Tokyo was plagued by insecurities with good reason. This insecurity led Japan to reinterpret events and frame her options to preempt subjugation, and led Japan to a series of disastrous decisions that set her on the road to War.

Japanese expansionism into Manchuria in 1931 was mandated by a belief on the part of the Japanese elites in the Nazi Germany's concept of Lebensraum (living space), which was essential for the continued prosperity and logical expansion in the realization of the nation's logical next steps in her Manifest Destiny. As part of her larger strategy, Japan encouraged the colonial expansion of settler colonies in Manchuria, with over 850,000 Japanese subjects moving to the region (O'Dwyer 2015). The settlers themselves had tremendous motivation in settling in Manchuria, and showed tremendous “determination and initiative (O'Dwyer 2015: 4) in urbanizing the new lands in Manchuria, becoming a development force in their own right and negotiating their own territoriality, space and existence vis-à-vis the Japanese state and other imperialist powers. By 1940, Japan entered into the Axis Pact Alliance with Nazi Germany and Italy, endorsing an alliance that designated Asia as Japan's primary sphere of influence. As the war raged on, Japan mistakenly believed that it was necessary to pre-empt the entry of United States into the War through a preemptive strike on Pearl Harbor.

Like today's China, many Japanese elites at the turn of the twentieth century, viewed these developments as little more than racist containment of a rising Japan, being denied her rightful place in modern East Asia. The contradiction between Japan's domestic social concern for egalitarianism and her foreign policy ambitions widened as liberalism gave way to military 
radicalism and ultra-nationalistic mood at home, setting her on a disastrous course to war. This shift of the tame nationalism of Meiji and Taisho Japan to the ultra-nationalism of the Showa Era grew in part due to insecurity, in part from imperial ambitions but also from a genuine sentiment to eradicate the shame and disrespect that the other colonial powers had shown Japan despite her achievements. In short, it was a fight for honor as much as it was for ambition and insecurity. Ironically, it was Japan's quest for a better human condition, independence and equality with the Western powers that saw the rise of Japan in pre-War East Asia, and ultimately down the path for War (Shimazu 2006). This remained the basis for Japan's quest for status and power in pre-War and arguably postwar International Relations.

\section{The San Francisco System and the Making OF AN “ABNORMAL" JaPAN}

With the surrender of Japan after the bombing of Hiroshima and Nagasaki in 1945 , the dynamics of the security landscape changed drastically. Japan, as the rising hegemon in East Asia had not only been thoroughly vanquished by the United States, but for the first time in history, has had a foreign power occupy mainland Japan. Japan's quest from the Meiji era onwards to learn from the West and become a respectable power in East Asia has now ended in tragedy, as United States deliberated on the fate of Japan. With the treatment of interwar year Germany in mind, the Occupation authorities in Japan needed to ensure that militarism in Japan did not emerge again, and that Japanese society needed to be thoroughly disarmed. From the Japanese perspective, it was a period of great uncertainty and insecurity. The great project that the Meiji elites started, and subsequently Taisho and Showa elites had promised had ended with a nation exhausted and stripped of her sovereignty.

The Occupation brought about a shock arguably greater than the defeat, as for the first time, the autonomy and the question of national self-determination has been taken away. The great project of building Japan into a great power since the Meiji Restoration was resulted in a nation exhausted and sapped, and sovereignty lost. Even more horrifying for most Japanese is the possibility that the Sovereign of Japan, the muchrevered Emperor would be held responsible for the war. Given the pride of the Japanese people in the uninterrupted lineage of their Sovereign, this 
was extremely untenable. The pre-war propaganda of the savagery of the American race did not help either. Thus when confronted with an enemy who had fought and defeated the Emperor's Imperial Army, who acted in such unexpected manner-many Japanese were in awe. Not only did the Occupational authorities requested aid from Washington D.C. to feed the starving civilians, there was no massacres as many expected. The American troops that arrived had behaved professionally. Most importantly, the decision of President Truman's administration not to hold the Japanese sovereign responsible for war was a political masterstroke, as it engendered the gratitude of the Japanese nation, laying the firm basis for cooperation between the United States and Japan ever since.

From the inception of the Occupation to the signing of the Treaty of San Francisco（サンフランシスコ講和条約/San-Furanshisuko kōwa-Jōyaku) and the Security Treaty between the United States and Japan (日本国とア メリカ合衆国との間の安全保障条約 Nipponkoku to Amerikagasshūkoku to no aida no anzen hoshojoyaku) in 1951, Japan unwittingly found once again faced with drastic changes in her external environment. These two treaties laid the foundation of what is now known as the San Francisco system. With the onset of the Cold War, the United States instituted a system of alliance from this period, signing a series of bilateral alliances with Japan, South Korea and to a lesser extent, entering into arrangements with Singapore, Thailand and Taiwan to confront the Soviet bloc. Japan had little opportunity but to participate as a primary member of the United States' alliance bloc.

The domestic mood in Japan in the 1950s was one of great trepidation and hope (Richardson 1974). The six years of occupation heralded a new era where the Japanese adopted elements of American popular culture. Japan transformed domestically, picking off the democratic experiment they left off during the Taisho era, with two important differences. First, the United States with over two centuries of democratic experience was actually then an active domestic actor in Japanese politics, designing and imposing institutions within Japan. Such close proximity not only imbibed Japan with democratic institutions, but endeared Japanese people to all aspects of American culture. Replicas of the Statue of Liberty and Mount Rushmore were erected in Tokyo's "America Fair", baseball games were held between Boston Red Sox and Yomiuri Giants and students of Waseda and Keio Universities, and live models were parading in modern swimsuits in Tokyo's department stores (Taylor 2014). 
Second, the Americanization of Japanese society, alongside the onset of the Cold War and the Korean War did not automatically led to the complete domination of the United States in Japanese politics with no room for local elites. In fact, many of the pre-war elites were still functioning as official intermediaries - the best example is that of Nobusuke Kishi. Despite the change of heart in Washington D.C. to turn and rearm Japan for the Cold War, the institutions that the Occupation authorities had built turned out to be resilient enough to withstand American pressure for remilitarization.

Third, the postwar period ushered in a new ideological framework. Japanese people celebrated both pacifism and democracy, and saw these two ideational influences as facets of the same coin. With the Japanese preference for egalitarianism, the Japanese pursuit of social democracy sits extremely well with Pacifism, and enabled the postwar Prime Ministers (starting with Yoshida Shigeru) to withstand demands from the United States to rearm by referring to the widespread public dissatisfaction as well as the Constitution put in place. The popularity of left-wing parties such as the Japan Communist Party (JCP) and the Japan Socialist Party (JSP) certainly help limit political appeal of American strategic agenda in the initial years.

Japan instituted a system of economic realism for the next four decades, with the LDP practicing a very narrow interpretation of Article 9 of the Constitution that limited remilitarization. This strategy was realpolitik, and did not make Japan anomalous as it reflected the changing realities of competitiveness in the global system in the postwar period. Economic power rather than concrete military strength mattered more than anything (Pyle 2007: 259; Dower 1988: 315). This system sat very well to the dominant political development in Japan as there was some sympathy within the country for Russia and China, probably because Japanese were familiar with the egalitarian ideals. Egalitarianism is deeply embedded in Communist and socialist political thinking, and this is compatible with Japanese perchance for social justice for all. The success of Japan's economic realism however did not stifle discussions of restoring normalcy of the Japanese state and the prospects of Japan gaining the respect and status it deserves in the international system.

The origins of what is the discourse on Japanese "normalization" have their earliest roots in narratives, thinking and institutions built during this period. Ichiro Ozawa, a dominant LDP politician wrote the bestseller "Blue Print for a New Japan" in 1984 was the first to use the 
idea of a "normal" nation even though these ideas have been discussed as early as the 1950s. The 1980s has seen the emergence of a new and more confident Japan, as indicated by the rush of intellectuals, policymakers and politicians who publicly argued that Japan should become more assertive vis-à-vis the United States. Some scholars have argued that it is mandatory for Japan to become "normal" at the expense of the Pacifism that she had built up over the years (Middlebrooks 2008). In the previous decades, even though the sentiments with regards to constitution revisionism and strengthening Japan in the alliance relationship, these grouses are usually articulated more subtly. However, by the 1980s, Japan's ascendance as the world's second largest economy has raised the confidence of many Japanese commenters, coinciding with the "golden" age of postwar Japan. Table 2.1 below captures the essence of Japan's foreign policy posture vis-à-vis the dominant hegemon and the rising power, as well as the technology and acquisition pattern of Japan historically.

\section{Mainstream Conservatism in Japanese Politics During THE COLD War}

The LDP's dominance in Japanese politics provided much political stability for Japan's economic development both internally and externally. For much of the Cold War, the LDP advocated for conservatism, which has come to be known as "postwar conservatism" since the administration of Hayato Ikeda to Keizo Obuchi. This Conservatism is defined by LDP as a party that did not abandon the weak, pursue enlightened self-interest based on the principle of international cooperation and a preference for fiscal health that provided for inter-generational fairness in terms of assets and opportunities (Funabashi 2016). Japan's social policies very left wing, very socialist and in effect, Japan pursued what was termed as "social democracy" at the very outset (Satoh 2018, Personal Communication).

The dominance of the LDP was due to a few factors: the institutional advantage that the "first past the post" electoral system conferred the incumbent party; the traditional Japanese culture that rendered acquiescence with the ruling party, and the pork-barrel politics phenomenon and System support explanation by which people voted in favor of the system but not the LDP (but in the process viewing that there were no other choices other than the LDP) (Schneider 2006; Tanaka 2007). The LDP cultivated exceptionally strong ties with the bureaucracy (Richardson 1974) with many senior bureaucrats leaving to serve in the Diet, and 


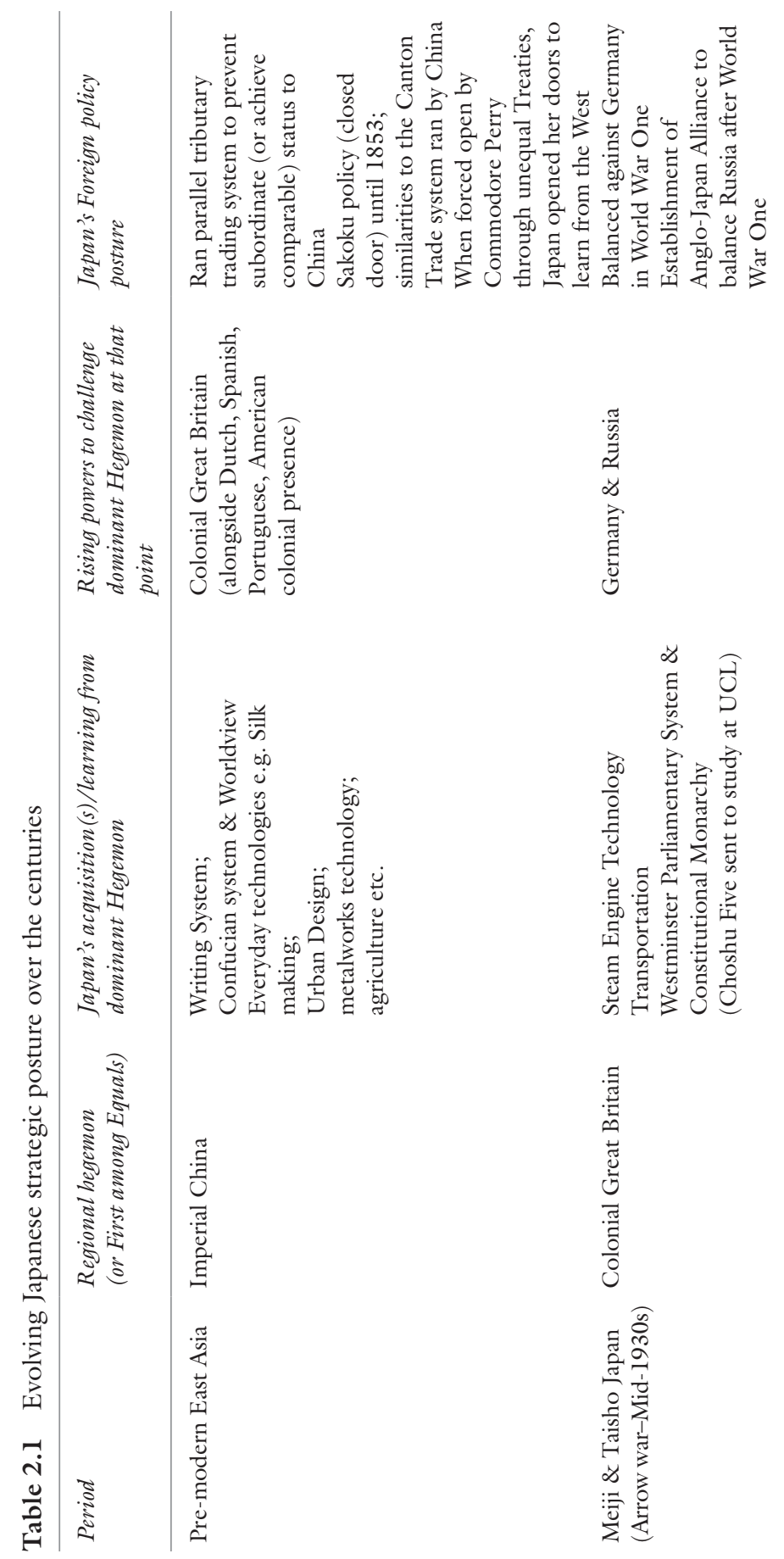




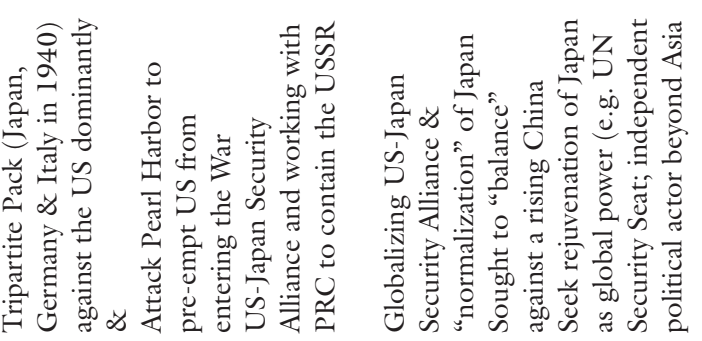

雚

$\widetilde{1}$
$\infty$

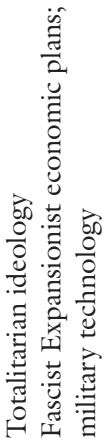

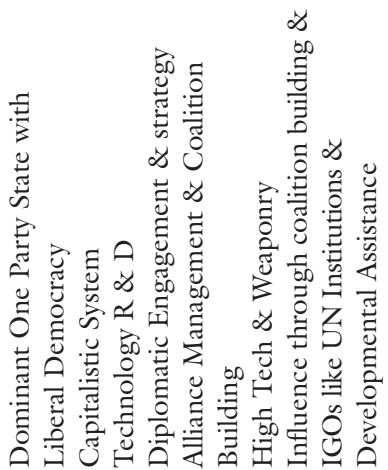

预

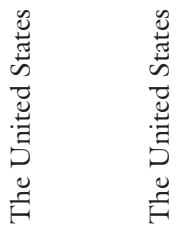

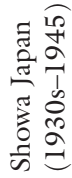

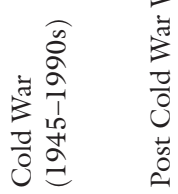


served as an incubator of sorts to match emerging political talents with local power politics and interests-all rallying around variants of the same conservative political ideology. One might even suggest the LDP actually constitutes five to six different parties, if one assumes that each faction is a party in itself. The factional horse-trading enables the exchange of interests and considerations, rendering the LDP a party machinery that is often able to coopt agendas and aspirations across a large spectrum of the Japanese political universe. To that end, the LDP has been called an oxymoron as it is arguably neither truly liberal nor democratic in her practice of politics. Lastly, the dominance of the LDP is also largely a function of the support of the United States. The shift from US goals in rehabilitation to containment meant that handpicking certain Conservatives to govern would ensure Japan stay staunchly anti-Communist and pro-American. The subtext meant the difficult understanding/interpretation of history between the United States establishment and these rehabilitated Japanese warriors would need to be swept under the rug.

Japan's relative political stability and economic prosperity since the 1950s has been underpinned by three important pillars that have been put in place since the 1950s. First, Japan adopted a new Constitution in 1947 that has guided Japanese politics, social development and foreign policy since 1947. The Constitution was widely seen as an instrument that was hoisted and imposed upon Japan, and was highly resisted by many Japanese officials at the time of its conceptualization. This resistance gave way to grudging acceptance but has since evolved into a wholesale embrace by most Japanese people. Second, the Japanese adopted Pacifism as the dominant political philosophy and worldview for politics and international relations. In mainstream Japanese politics, this is enshrined not only in the Article 9 of the Constitution, but materialized in the ideational framework by which Japanese people view the world and successive generations of Japanese administration have premised their policies upon. The Yoshida doctrine, enacted by the Shigeru Yoshida mandated that Japan followed the lead of the United States in strategic affairs, whilst focusing her efforts on economic development and national reconstruction. This principle provided guidance to Japanese politicians and nation with regards to her domestic and foreign priorities, and ascertain the amount of resources, attention and efforts be given to global affairs and international commitments versus domestic priorities e.g. the building of the Japan Self-Defense Forces. Third, the US-Japan Security Alliance, embodied by a Treaty signed in 1951, (reinterpreted and updated in 1960), became the single 
most important instrument to reconcile the exigencies of national security concerns with the demands of pacifism. The 1951 Treaty saw Japan regaining sovereignty and the 1960 Treaty decisively instituted the alliance as a central pillar in Japanese politics and foreign policy. The Yoshida doctrine and the US-Japan Security Alliance taken together allowed the flourishing of a genuine pacifist democracy at home in Japan, and enabled Japan to maintain an asymmetric relationship with the United States, relying on the US for nuclear protection, security protection and a privileged position in US grand strategy in Western Pacific.

These three pillars-the Constitution, Pacifism and the US-Japan Alliance provides a powerful cocktail for the making of a prosperous and forward looking Japan. Utilizing an export led economic growth strategy, Japan achieved double digit growth throughout the 1970s and 1980s. Japan's innovation in manufacturing, particularly in sectors such as electronics, automobiles and consumer goods, and her preferential market access to the United States, Europe and Asia, saw her economic and trade linkages intensified across the world. Japan overtook West Germany as the second largest economy by 1967, and Japan's economic growth continued growing at a double-digit growth rate in the 1970s. With this new found economic prosperity, Tokyo sought to increase her political clout through the application of Fukuda doctrine in 1977. Japan built a program of Overseas Developmental Assistance (ODA) to engage regional countries in Southeast and East Asia in order to improve her security in a comprehensive security. This growing political and economic importance is reinforced by a corresponding rise in Japan's soft power as her traditional and popular culture became extremely popular across the world. By the late 1980s, Japan entered into an era of renaissance, cementing her position as the de-facto leader in Asia. Her evolvement from a subjugated defeated military power to a modern peaceful democratic economic superpower was complete.

The rise of a more confident and assertive Japan was however not without problems. The 1980s saw the emergence of unprecedented friction in Japan's foreign relations with the United States and China (Hoppens 2015; Koga 2016). As Washington and Tokyo quarreled over trade deficits, technology co-operation and transfer (Green 1995), alliance management in areas of risk distribution and burden sharing, nationalistic narratives began to emerge in both the United States and Japan. Even though decades have passed since the Second World War, the burdens of the war related issues lingered on. The Chinese reaction to Japanese Prime 
Minister Nakasone's Yasukuni Shrine visits (1983 and 1985) and the controversy over history textbooks took the Japanese by surprise. After all, Prime Ministers Ohira Masayoshi, Suzuki Zenko and Nakasone Yasuhiro had visited the shrine a total of 21 times but it was a non-issue with the Chinese government until 1985 (Sakamoto 2014). Tokyo learnt that Japanese aid and assistance cannot completely eradicate memories of Japanese Imperial Army's conduct and sins during the Second World War-be it in Philippines or Korea, China or Indonesia. Domestically it is also difficult to do so, as social memories are increasingly contested even up till today (Tamanoi 2009; Takahashi 2006, 2010). Diplomatic difficulties aside, the Soviet threat however provided the strategic clue to ensure that China, Japan and the United States remained stable.

Notwithstanding these difficulties, Japan's relations with the Reagan's United States and Deng's China in the 1980s still looked to be the "Golden Age" in recent Japanese diplomatic history. During this time, Japan has grown strong, and domestic rhetoric has encouraged many in Japan to think of themselves as being somewhat as a challenger (or alternative) to the United States herself, besides the Soviet Union. At the same time, China-Japan relations were entering into a new phase. As Chinese society emerges out of two decades of political excesses into an age of reform and openness, Chinese civil society began debating the issues of war responsibility vis-à-vis Japan while China was benefiting directly from Japanese help and assistance. The Land of the Rising Sun, in short was back at a leadership position in East Asia regional system.

Foreign diplomatic difficulties and rising domestic confidence therefore led to the emergence of a new and virulently nationalistic discourse in Japan. The 1980s saw the emergence of a few of these politicians who argued explicitly for an end to Japanese exceptionalism of being a pacifist super-economic power. In short, Japan should reconsider elements that had rendered her "abnormal" and seek to "maximise" Japan's power and international status. Japan's prestige can be enhanced through the lifting of her reputation through the reconsideration of Japan's international contributions and commitment to the San Francisco system principally through the modification (or eradication) of the three central pillars: the Constitution, the US-Japan Security alliance and the wider framework of Pacifism and the role of the military in Japanese society. 


\section{The Rise of Neo-Conservatism: From Normalization TO THE REJUVENATION OF JAPAN}

The 1990s heralded systemic changes that fundamentally affected the positive outlook for Japan and challenged the foundations of her strategic outlook. First, the collapse of the USSR meant not only the loss of a common strategic enemy with the United States, but also the raison d'être for the existence of the US-Japan alliance put in place in the 1950s at the start of the Cold War. Second, the economic rise of China presented a sense of ontological threat to Japan, particularly so as Japan had undergone a decade of deflationary growth. Third, the relative stability of the Cold War years had been replaced by an era of escalating security challenges that directly or indirectly involve Japan-from the Taiwan Straits Crisis, the dispute over Senkaku islands to the North Korea threat. Fourth, there were extra-systemic factors. Japanese elites and people were shell-shocked after forking out $\$ 13$ billion USD in contribution to the first Iraqi war, the Kuwait government did not include Japan in the vote of thanks recorded in the New York Times it took out. This was ostensibly because Japan had not contributed personnel, but in reality was because the Japanese Foreign Ministry had asked the Kuwaitis not to acknowledge Japan. Even though Japanese funds contributed to the War effort, and contributed mine clearing operations in the postwar era, there was a deep sense of outrage i.e. the MOFA's plan had backfired spectacularly. The overchange in the domestic narratives led to the passage of the 1992 International Peace Cooperation Law that saw the dispatch of Peacekeeping troops to United Nations Transitional Authority in Cambodia following the conclusion of the civil conflict.

The origins of the shift of the mainstream politics towards the right of center in Japanese politics have been a long time in the making. This correction is partially a result of generation change coinciding with the systemic changes in the Northeast Asian security environment and a domestic slump in the confidence of Japan's future, partially a result of the erosion of pacifism as the elderly generation in Japan dies out. The efforts to rethink Japan's politics and foreign policy in accordance to a new kind of Conservatism really set in with a change in both domestic and foreign policy circumstances and were in a large part facilitated by rise of internet and social media in politics.

The LDP's mainstream conservatism did not really change until the tenure of Junichiro Koizumi. As the fourth longest serving Prime Minister, 
PM Koizumi is one of the most well-known Japanese Prime Ministers in recent times. He built a formidable reputation for being maverick in Japanese politics. During his tenure, he redefined the role of the Kantei (Prime Minister's Office), and the Office's relationship to the traditional media, the bureaucracy and the LDP party machinery.

Koizumi's very shrewd advisors, in particular his principal secretary, Isao Iijima played an extremely important role in helping Mr. Koizumi craft his image and manipulate the media, in turn allowing him to command a popularity unprecedented in postwar history of the LDP. Through reaching out to gossip magazines and tabloids, and through his direct messages to the Japanese electorate on social media, Koizumi's image as a reformer in resisting traditional LDP politics empowered him as an agent of change. His ability to direct his political messages and received support for them is unprecedented, and to that extent enabled him to secure the support to undertake his political agenda.

The Prime Minister was also insistent on naming his own liaison officers to the powerful Ministries, rather than have the Ministries assign their own preferred officials to the Kantei. This move to rein in the bureaucrats has continued to this day by the Abe administration with marked success (Winter 2016).

As a politician who was relatively clean during his 30-year-old career, Mr. Koizumi was always careful about accepting courtesy calls from patrons and backers, as well as cautious about the sources of political donations - and in the words of Mr. Iijima himself, Koizumi is one of the "cleanest and most scrupulous politicians in Japan" (Strom 2001). He sought to enforce the law punishing politicians who receive money to act as go-between in arrangements between private and public parties, and to prevent collusive bidding for government projects, and political neutrality of public servants. This provided him with a legitimacy that enabled him to reduce the influence of lobby groups and special interests, "end the power of vested interests and old-fashioned customs, including the privileged circle of journalists" and eradicate the ability of the bureaucrats who dictate to the Kantei (Strom 2001). Koizumi wanted to end the consensual and moderate forms of politics and politicking which policies were implemented step by step through persuasion and compromise (Funabashi 2016).

The ferocity and the unconventional methodology by political strategies took on the traditional LDP machinery by surprise. This change was most exemplified by Koizumi's attempt to reform Japan Post. This is an 
institution revered by both the ordinary Japanese as well as much of the LDP elites. Japan Post was said to be the world's largest financial institution, with 24,700 branches and banking and insurance assets of $\$ 3$ trillion. Koizumi regarded Japan Post acted as a slush fund of sorts for political elites and piggy bank for bureaucrats who often relied on it as a source of cheap capital for wasteful projects (Will 2006). Faced with opposition from his own ranks, Koizumi recruited and fielded 37 candidates against his LDP opponents (many senior politicians) in the 2005 election, defeating most of these party elders in the process. The Japanese people's penchant for a strong leader was exemplified by their love for PM Koizumi as he put up new signals and symbols (visits to the Yasukuni Shrine), resistance phrases (let's destroy LDP), not to mention fielding a host of political assassins to kill off his opponent (Faiola 2005; Will 2006).

At the same time, it must be pointed out that Koizumi's success during this period could be attributed to the electoral reforms in Japan. One should not assume the increase in interest in a particular policy area such as national security to be driven by changes in candidate or voter preferences, but rather that there is a possibility that it is driven by candidates' efforts to survive under new electoral rules or new political institutions (Catalinac 2015: 14). Koizumi's politics have made it possible for the first time that national security and foreign policy have become platforms by which candidates could compete on during elections.

Koizumi's populism unfortunately was contemporaneous with a rabid nationalism that drove the LDP conservatism in a different way. Koizumi adopted a nationalistic posture that explicitly identified China as not only the "other" in Japanese nationalism, but as an existential security threat that Japan was destined to stand up to. This is one important differentiating aspect of the neo-conservatism from the previous generation of conservatism during the Cold War era.

This had had two important effects. Koizumi's ignorance of warnings from China not to visit the Yasukuni shrine drove Sino-Japanese relations to deteriorate rapidly over the period he was in power. From the perspective of the Chinese (and some Japanese), Koizumi is known for his mishandling of Sino-Japanese relations. The period of his administration saw the outbreak of some of the worst protests in contemporary Sino-Japanese relations (Chen-Weiss 2014). From the Japanese perspective, the political effect of Koizumi's practice is to desegregate the burden of history from Japan's China policy. By constantly ignoring China's political rhetoric and diplomatic pressure, Koizumi desegregated historical issues from bilateral 
relations, and seize the political advantage from China. Even though this set back Japan's relations with China, it also meant that Japan could chart her own path over issues like the East China Sea disputes where critical national interests are at stake. It also meant that Japan could effectively enhance the US-Japan alliance with vigor without worries, particularly with the neo-Conservatism that he was advocated became mainstream both within and outside of China.

The second important effect is that from the early 2000s onwards, neoConservative elites sought to revisit the ideas of postwar system in Japanese domestic politics and the central pillars of Japanese foreign policy with vigor. The neo-conservatives is a reactionary movement against the postwar leftists and liberals, and the elements of traditional culture and national pride are being used to rebuke liberals and leftists, as the latter are being accused of denying Japan's traditions. In terms of foreign policy, even as the Japanese elites looked to reaffirm the US-Japan Security alliance (Dian 2014), the new LDP elites undertook a series of administrative measures to sidestep the Constitutional constraints in order to legitimize/legalize the actions. This pragmatism appeared to reconcile the exigencies of the moment but did not stop the Japanese elites from wanting to move ahead with more substantial legislation to effect this normalization process. Supersizing threats and effectively managing the media content therefore was one of the most important ways forward for the LDP elites to gather the support and moment needed for this.

Shinzo Abe built on Junichiro Koizumi's "reactionary" conservatism in a different way. Compared to Abe, Koizumi is seen as theatrical, liberal maverick. Even though Abe's methodology is not nearly as populist as Koizumi's, he was certainly far more methodological. Without the flare Koizumi exhibited with his openly flamboyant "resistance", Abe has been nothing if not coldly calculating in the advocating of his political agenda, moving away from the traditional way of politics and known brand of trusted postwar Conservatism. Despite this, it is still questionable if Abe would be able to capitalize on his time in the office to centralize and run foreign policy "Kantei" style like his two most popular predecessorsNakasone and Koizumi. Abe took to abstract ideology and nationalist imagery (Mark 2016), something which Koizumi had not done a lot on. Hence starting with Koizumi right up to the present, Japanese politics took a relative sharp turn as both the Japanese elites and the people started to debate seriously as to the possible remedies that are able to lift the country out of its economic slump and also to recalibrate so her policies 
could face the challenges of the future. To that extent, three most important pillars of postwar Japanese politics and foreign policy need to be reconsidered.

First, Japan needs to rethink her role as a Pacifist power. This essentially is a question of rethinking and reinterpreting her political and diplomatic identity. Tokyo has to consider what kind of international contributions it should and could possibly make in relation to her pacifist identity and to what extent should this change and if so in what direction. In particular, how should the Yoshida doctrine and Japan's military fit into the overall current trajectory of Japanese foreign policy. At the same time, how should this pacifism speak to the concerns of the younger generation of the Japanese, particularly as they search for their place in the world and their views on the future as well as on the past.

Second, how could and should Japan overcome the constraints of her foreign policy vis-à-vis the Japanese Constitution, particularly with regards to Article 9. The challenges are both political and legal in nature. They are political because in essence, the Japanese Constitution is a deeply cherished statement of apology extended to Japan's neighbors as much as it is an important maker in Japanese national identity. They are legal because the Constitution of any country should be considered as "higher law", even as many Japanese regard that the Constitution was a document hoisted and imposed by the occupation authorities. Even as the Japanese people have over the last two generations gone out to embrace this document, should the Japanese people continue this as both a higher law and an institution or should it be amended and changed with times?

Third, Japan needs to understand how to position and recalibrate her alliances to meet the challenges of the changing times. In particular, how should the US-Japan alliance be handled, and how should this alliance be calibrated in relation to the rest of her foreign relations, particularly with Japan's closest neighbors? Should domestic institutions, even important ones such as the Constitution be changed to fit the exigencies of the alliance? How should the Alliance evolve to accommodate Pacifism and the Constitution?

\section{The Contours of the Debate on Japan's Rejuvenation}

Ichiro Ozawa, one of Japan's most prominent politicians, was one of the first persons to have suggested that Japan needed to consider making political change to become a "normal" nation (futsu no kuni). His book 
published in Japanese in 1993 (English 1994) "Blueprint for a New Japan; the Rethinking of a Nation" (Nihon Kaizo Kei Kaku) (Ozawa and Gower 1994), argued that Japan need to increase international contribution, security cooperation with the United States and participate actively to build a new international order. There are parallels drawn between Ozawa and Koizumi, with both politicians suggesting they want to destroy the LDP to reform the parties, with Ozawa wanting to seek principled political reforms using old school reforms and Koizumi keen to bring about economic reforms via domestic restructuring (Mulgan 2015).

There are of course different ways to think about Japan's foreign and security postures using different typologies or categories (Soeya et al. 2011). Soeya Yoshihide, one of the foremost intellectuals in Japan today have advocated Japan should travel down a path towards what he calls "middle power diplomacy" (Soeya 2011: 22-97)—a characterization that exhibits the typical Japanese modesty that understates both Japanese achievement and abilities. As much as this idea might appeal to many Japanese, it is also true that Japan's wanting to join the UN Security Council and contribute to international community might not sit well with such political and diplomatic modesty. For most part, the security and foreign policy narratives today are very different from yesteryears (Vosse et al. 2017). Cheol-Hee Park has divided and placed noted intellectuals and politicians in Japan in a four-quadrant diagram where one axis represents the view of international commitments (from important to unimportant) and another axis measures the degree of militarism (i.e. from anti-military to pro-military). Most of Japanese politicians such as Nakasone, Ozawa, Koizumi and Abe will fall into the quadrant which is pro-military and regard international community as important. Only ultra-nationalists would be pro-military and disregard international commitments as unimportant (such as Shintaro Ishihara). Politicians of the previous generations are generally anti-militaristic even if they regard international commitments as being unimportant. Park notes that for most politicians (Ozawa, Ishihara, Nakasone, Koizumi) there is a general consensus that Japan needs to strengthen her political leadership, tweak her Constitution, implement some sort of crisis management and increase Japan's international commitments. In essence, Japan's normalization/ rejuvenation would require increased westernization of Japan and an emphasis on institutional engineering (Park 2011: 98-121).

Richard Samuels, one of the world's most respected Japan specialists, argues that security narratives within Japan can be split into four different 
worldviews (Samuels 2013). First, there are those who distrust foreign entanglements prefer Japan acquire and sustain an independent military capability and domestic technological base. From their perspective, Japan should be autonomous and self-reliant with equidistance from both the US and China. Japan would and should pursue an active international agenda only if it is able to do so. Samuels argue that Pacifists and Gaullists who prize sovereignty above all else, and a modern posterboy of this narrative will be Shintaro Ishihara. The second worldview are those that advocate a bandwagoning strategy with the rise of China. They lean towards the Chinese as they discount the China threat at the risk of alienating the United States. In this sense, they see greater democratization and pluralization of global power in a multilateral world. This category would probably include the links of former DPJ President Yukio Hatoyama and Ichiro Ozawa. The third worldview are those who seek to balance China. There are less attracted to China's economic rise and perceive that it might be better to hedge by balancing China militarily through a robust US-Japan alliance. They perceive Japan would be the best off and safest when US is the dominant player, and Japan is tightly entwined with the United States. This worldview is shared by the more center-right politicians of the LDP, such as Kishi Nobusuke, Nakasone Yasuhiro, and today's Abe Shinzo. Koizumi Junichiro is however more nationalist than right of center even though he is associated with the neo-Conservatives.

The fourth category are "integrators", who believe that there is no tradeoff between growing stronger relations with China and maintaining a tight alliance with the United States. In Samuel's words, they "fear China betrayal and Washington decline in equal measure" and they wield both a "shield and a sword". Samuels argue that the "pragmatic wing" of the LDP during much of the Cold War belongs to this camp. Needless to say, the last two decades has seen the dominance of worldview three in Japanese public narratives, where politicians and officials all call for a more muscular US-Japan alliance. But as Samuel notes from the study, it is ironic that despite the high conflict over Senkaku islands, few Japanese view the rise of Chinese military power as a key problem in bilateral relations (Samuels 2013: 1-6). The succinct typology encapsulates the positions on the three major challenges that actors across the political spectrum might holdConstitutional Revisionism, US-Japan Alliance and Pacifism, Global Engagement and the use of force. Understanding how these three important pillars or challenges are being addressed across the political spectrum by different politicians and scholars are critical for narrowing down our 
understanding of the contemporary discourse on Japan's rejuvenation. The following section unpacks the central ideas and debates in each of these themes.

\section{The Central Pillars of Rejuvenation}

\section{Theme One: Constitutional Revisionism}

Compared to the 1889 Meiji Constitution, the 1947 Constitution made major progress in a few respects. First, the sovereignty of the 1947 Constitution rests with the people, as opposed to the Emperor. Second, it offered universal suffrage for women and third, it emphases human rights, equality before the law and non-discrimination on the basis of race, social status or family origins. The Meiji Constitution provide a stipulation of rights within the confines of the law as dictated by the Meiji Emperor, in particular listing out the duties and responsibilities of the subjects (See in particular Chapter two of the 1889 Constitution) during peace time.

The initial ideas of the 1947 Constitution shocked many members of the Japanese elite and the people. The elites, manifested by the bureaucrats were most worried about the prospects of how the institution of the Emperorhood related to the Constitution, particularly if sovereignty rested with the people, but not the Emperor. The real issue for many in the right-wing faction of the Liberal Democratic Party was (and still is) the existence of Article 9, which removes the war making power of the Japanese nation. As the following passage published in the Japanese newspaper shows, the Japanese response did not see the necessity or the merit of Article 9 in the draft of the 1947 Constitution made public:

Nor are we without some misgivings concerning the other focus of this constitution, the eternal renunciation of war. We are convinced, to be sure, that an aggressive war should be banned for all time, but should we not be left with the right to fight a war of liberation, in case a foreign power should commit aggression against us and attempt to subject us to a state of slavery? If the right to wage a war should be totally given up, then the nation should have a status of permanent neutrality recognized, as is the case with Switzerland, and guaranteed by the United Nations, by force if necessary. While we would be the first to vote for the perpetuation of peace and abolition of war, we would also defend our nation's life and independence even at the cost of our blood ... (Yomiurihochi, 8 March 1946) 
The reaction of the Japanese society to this Constitution was diverse. There were complaints about the language of the draft being imprecise and repetitive. The reaction of the Conservatives was naturally aghast, with more radical wing of the Conservatives asking for the Article to be dropped, along with others mounting legal challenges to Article 9 in the Japanese courts. The Japanese judiciary avoided ruling on these political challenges, preferably sending these requests back to the political process. (Fukui 1970). The Conservatives saw the Constitution as a foreign imposed document capable of "weakening the nation" with "the unwarranted suppression of the ideal of the state and patriotism and excessive fragmentation of the powers of the state'.

Even though the Conservatives (alongside the leftists) lead the criticisms against this abhorrent development, the Constitution was adopted nonetheless. In embracing this Constitution, the LDP, led by Shigeru Yoshida was perceived to be making a neo-realist decision as it allowed Japan to maximize her interest and latitude, and accorded Tokyo the maximum power that Japan could muster in such a situation. Subscribing to the Constitution allowed Japan to realign the political priorities and foreign policy vis-à-vis the United States, channeling resources and strategic attention to domestic priorities such as rebuilding the economy. The Japanese elites quickly discovered that the Constitution provided an extremely efficient shield ironically against the United States who had by the Korean War changed her mind about the expectations of what Japan should or should not do. Yoshida was extremely adept at using the Article 9 of the Constitution to barricade against US demands for Japan to remilitarize, and the LDP successfully use this narrow interpretation for a good four decades (Pyle 2007: 236). At the same time, in his memoirs, Yoshida argued that the Constitution is entirely "foreign imposed". General MacArthur, he revealed, had told him that the Far Eastern Commission had come to the decision that the Japanese people were free to adjust in a year or two after the Constitution come into effect as the Allies wanted to show that this was entirely born out of the will of a free Japanese people (Yoshida 2007: 117-118). In Yoshida's eyes, Article 9 need not be revised, but he did not preclude that it could be revised, but it has to be a decision of all the people's careful deliberation (Yoshida 2007: 119).

Hatoyama did initiate moves towards Constitutional revision through the submission of the Constitutional Revision Committee but was forced to abandon due to opposition in the Diet. Nobusuke Kishi followed in Hatoyama's footsteps by also commissioning a research group on the revi- 
sion of the Constitution, and this finding of the research group in 1964 were shelved by Prime Minister Hayato Ikeda to avoid antagonizing public opinion that was fiercely anti-militaristic. The debate was particularly intense during the 1950s as the dominant theme of Japan's domestic politics tittered on pro-amendment and anti-amendment of the Constitution (Nagai and Toshitani 1986). In 1955, when the Liberal Democratic Party was founded, Nobusuke Kishi, insisted that the LDP sought constitutional revision be adopted as one of the founding objectives (Fukui 1970: Chapter 8; Johnson 1995; Schaller 1995, 1996).

The peace constitution sits uncomfortably with the Conservatives in few respects, providing the principal reasons for the Conservatives to push for its amendment. First, the Constitution is viewed by supporters, including its architects as the principal mechanism to prevent Japan from ever going down the "slippery slope of militarism", but to its detractors it is both a hallmark of shame and a permanent chastisement on Japan, despite her postwar achievements and rehabilitation efforts. Second, the Constitution, particularly Article 9, hamstrings Japan's sovereign choices to use force, particularly in a rapidly declining security environment. It therefore unfairly constrains successive generations of Japanese to fend for themselves. Third, Article 9 sits uneasily with the existence of Japan's security apparatus, particularly the Japan Self-Defence Forces and the attendant supporting institutions, apparatus and legislations. Amending it to acknowledge the existence of the JSDF is the right move as it provides legal mandate and remove this contradicting hypocrisy as one of Japan's most important public institutions. Fourth, it provides legitimacy to the historical narratives that the Conservatives have been hawking since the end of the Second World War, and lends legitimacy to the over exercise and rightwards push in mainstream politics. Fifth, removing Article 9 also helps facilitate Japanese aspirations of "globalizing" her strategic reach and geopolitical influence. This has two dimensions: first, it is born out of a genuine altruistic sense of wanting to contribute to global peace and humanitarian missions and second a desire to support US-operations globally to upgrade the US-Japan alliance per se, so as to provide a global dimension to Japanese Foreign Policy.

The strategy by which the LDP is advocating the changes is straight forward. The goal of revising the Constitution has been central to LDP and Japan's politics during the 1950s and 2000s but it has never materialized. The 2012 Senkaku dispute provided the golden opportunity for the 
new Abe administration to push for its rejuvenation agenda and advocate for Constitutional change. The Conservatives had suggested that the current Constitution is not a Japanese Constitution since it was imposed during the Occupation Period and suggests that a new Constitution should be made by Japan itself. The second strategy is to suggest that the Constitution has outlived its utility and does not meet the exigencies of modern Japan's needs, and suggest that additional clause be introduced into the Constitution. Revision of the Constitution to meet the requirements of the present is not only important but necessary. A third strategy is to suggest that any revision can only come about as a result of democratic will of the people as the ultimate sovereignty rests with the people, not the government. Employing this narrative would mean that the focus has shifted on how to amend the Constitution as opposed to whether or not amendments should be undertaken. Thus, the narrative suggests that it is people of Japan, rather than the LDP that decides on the Constitution amendment (Takahashi 2013). In Prime Minister Abe's first term, he successfully managed to pass a law that paved the way for Japan to consider the prospects of Constitutional Amendment. In his second term, he has undertaken a series of step towards Constitution amendment.

\section{Theme Two: The Nature and Tone of the US-Japan Alliance}

The US-Japan alliance stands as one of the three important pillars in Japan's quest for rejuvenation. One of the most interesting aspect of the US-Japan alliance is how much the Japanese elites at the beginning of the postwar years all wanted to sought greater independence from the United States - albeit their very different political platforms and ideologies.

When Prime Minister Yoshida resisted the pressures for the remilitarization of Japan from Washington, the result was the signing of the San Francisco Treaty and the 1951 Security Treaty between the United States and Japan. This treaty was highly unequal and carried a tremendous price for maintaining the pacifist stance. It preserved many of the prerogatives of the US military, and in effect made Japan a military satellite state of the United States - giving US basing rights, power to quell domestic disorder, right to project power against a 3rd country without prior consultation, extra-territoriality in relation to the American servicemen, and compelled to recognize the government of Taiwan, thereby sacrificing any relations 
with the mainland Chinese government (Pyle 2007: 234). The resistance of the Japanese elites to aid in the American goal of spreading democracy worldwide led American elites to conclude that Japan has "no basic convictions for or against the free world" (Pyle 2007: 236). Yoshida believed that citing public opinion and narrowly interpreting Article 9 would shield Japan from the increasing demands made by Washington regarding militarization. This strategy was a realist one-in doing so and utilizing the pacifist shield, it allowed Japan to recuperate and refocus her efforts on domestic reconstruction. The terms of the 1951 Treaty were not ideal, but it allowed Japan at least to move one step away from having completely to do what it was told during the Occupation years.

One particular aspect that troubled Yoshida was the question of equality. His view of the US-Japan Treaty at the inception was that it should be viewed from an equitable perspective. In return for Japan's obligation to host US forces, the United States should therefore agree to defend Japan. Yoshida therefore felt that the US position that US forces are there simply because "Japan cannot defend herself" was a problematic gesture (Yoshida 2007: 215).

As a political arch rival of Yoshida, Prime Minister Hatoyama too sought a certain independence from the United States, even had he come to power at a time when there was intensifying domestic struggle within and between the Conservative and the Socialist camps. This of course led to the consolidation of the Liberal Party and Democratic Party, and of the socialist parties into the Liberal Democratic Party and the Japan Socialist Party respectively, known today as the 1955 system. Hatoyama was instrumental in normalizing relations with the Soviet Union. To some extent, this did help moderate the influence of the United States within Japan.

When Yoshida's arch rival Nobusuke Kishi was rehabilitated by the United States and subsequently elected as the Prime Minister, it was a boon for the US-Japan alliance. It is common enough to find narratives among critics of US-Japan relations that Kishi, in gratitude for his rehabilitation to the Occupation authorities has sought to decisively push for a renewed version of the US-Japan Security Treaty against popular wishes. This however needs to be qualified. First, American attempts to influence Japanese politics faced increased obstacles because there was widespread sympathy Japanese people have on the ground for left wing politics during the 1950s. Kishi faced tremendous obstacles in trying to push through the bill for the revised US-Japan security alliance. Second, one of Japan's 
most critical observers of Japanese politics and foreign policy Magosaki Ukeru observes that Kishi is seen as an extremely pragmatic politician who is always striving for Japan's interests vis-à-vis the United States. In pushing for the revised Treaty, Kishi wanted to eliminate the unequal aspects of the Alliance, including the elimination of the clause that empowered US authorities to quell domestic disturbances, a voice in the deployment of Japanese troops, and an explicit security guarantee from the United States in the event of an attack (Pyle 2007: 237-238). To this extent, Kishi shared Yoshida's vision: to rebuild Japan, economic reconstruction and restoration of independence would be necessary. Unlike Yoshida, Kishi viewed rearmament as necessary, but regarded Yoshida leaning too much towards the United States, and Hatoyama in leaning too far away from the United States. Kishi saw a more "balanced" and nuanced policy, and recalled that he spent $70 \%$ of his energy devoted to the revision of the US-Japan Security Treaty (Kitaoka 2016: 106). Prime Minister Abe argued that his grandfather's goal was indeed striving to have more independent relationship with the United States. The renegotiated US-Japan Security Treaty is a perfect case of Japan trying to obtain greater political leeway and independence from the United States rather than pliantly accept diplomatic subservience to the United States.

Japan's alliance with the United States grew more difficult towards the latter half of the 1960s. The single biggest issue facing US-Japan alliance was not the perceived aggressiveness of Khrushchev or a radical China detonating nuclear weapons, but from the deepening involvement of the United States engaged in an escalating war in Vietnam. A public opinion poll found the number of Japanese people who viewed the US positively had declined rapidly from the $45 \%$ in 1965 to $18 \%$ in 1974 , to the extent that US Ambassador Reischauer was spat upon during an engagement in Japan (Kosaka 2016: 153). The biggest challenge for the Sato Administration was the negotiation of the reversion of Okinawa and the negotiation of Japan's Three Nuclear principles (i.e. no manufacture, possession or introduction of nuclear weapons) with the United States (Hoey 2015). There is of course much skepticism, for it is an open secret that United States military in Japan did have nuclear weapons on board their warships for a better part of the Cold War.

The reversion of Okinawa (McCormack and Norimatsu 2012) brought about an important but understated development for the US-Japan alliance at that time - that of the transfer of control of the Senkaku/Diaoyu islands. 
Instead of transferring the islands back to the Republic of China (an US ally), the effect of transferring the islands control to Japan has created advantages for the United States: it awoke Chinese nationalism against Japan, and sowed the seeds of discord between Japan and China, and Japan and Taiwan, adding a point of contention between these East Asian countries. It bound Japan more tightly to the United States that ever before as a client state (McCormack 2007). By enacting a policy of "not taking sides" on the sovereignty and at the same time, suggesting the islands control are covered by the US-Japan Alliance, it creates a permanent role for the United States in the region's security architecture.

With domestic and international opinions turning against the Vietnam War as well as the cost of the operationalization of the Containment policy, President Nixon campaigned on the promises of bringing the United States troops home in a bid to achieve "peace with honor" in his Presidential Campaign. The United States also cut the dollars link to this goal as they realized they cannot honor this commitment. All these spoke to the relative decline of an over-extended country. In introducing the Guam Doctrine in 1969, the United States recalibrated their strategic outlook to achieve détente and arms control with the USSR. In particular, Nixon introduced the Vietnamization aspect of his doctrine, which essentially meant that the United States would extend the protection of her nuclear umbrella, but respective allies would have to shoulder their own defense. Even though Nixon's message was principally meant for South Vietnam, the effect of these US policies brought shocked Japan (known as Nixon shokku) (Frankel 1971).

This was not surprising, as Japan's role in the US grand strategy has almost always been taken for granted by Washington. Henry Kissinger had little interest in Japan as his found his counterparts "not conceptual" and that "they have no long-term vision, that they go for decisions by consensus", and that they were "prosaic, obtuse, unworthy of sustained attention", and regarded them as "little Sony salesmen" (Kissinger 1979: $321-25$; 1982: 735-46). For Japan, the move was both insulting and demeaning. The United States undertook secret overtures to the Chinese whilst preventing the Japan from speaking to the Chinese.

The US-Japan Security Alliance did not provide the kind of equality that the Japanese had hope. Tokyo realized from Washington's perspective, Beijing was the key, not Tokyo. The United States had hoped that the change in strategy would enable the United States to do more with less. A planned withdrawal from Vietnam, the operationalization of Guam 
Doctrine, and détente with USSR will change the strategic perspective in China. Beijing would face a declining United States, a growing Soviet threat and the prospects of a Japan rearming - that would prompt Beijing to welcome the US presence in Japan, not otherwise. The United States hopes that this alone would be sufficient to pull China towards the United States, and outweighed her desire to regain Taiwan, protect her Communist allies in Vietnam, and the ideological aversion for capitalism. Even though Nixon was an admirer of Kishi, who was Prime Minister Sato's half brother-there was limited respect that the United States gave to the Sato's administration insofar when the Alliance was concerned. Prime Minister Sato was also a protégé of Yoshida Shigeru, and sought a harmonious and cooperative stance with the United States, even though the rapprochement effectively ended the political career of Sato (Iokibe 2016: 232).

The dynamics of the 1970s was however quite different from the previous decade. Tanaka Kakuei strove to normalize relations with China, and Miki Takeo as his successor was keen to sign a Peace Treaty with Chinaeven though it did not materialize until 1978 during Prime Minister Fukuda's reign. The interest of Prime Ministers Tanaka and Miki were to insure that Japan was not left out in the Cold, but also proactively to engage China. As renown Japanese scholar Iokibe Mokoto noted, the practice of Japanese Prime Ministers visiting the United States as the first foreign visit is akin to feudal lords paying respect to the Shogun in ancient times. It is indicative of the importance of US-Japan relations and Japan's as a dependency — as Prime Ministers Tanaka, Miki, Fukuda and Ohira did in the 1970s, albeit for different reasons (Iokibe 2016: 231). Prime Ministers Ikeda and Sato went because of the privileged position of the United States, Tanaka and Fukuda went because of other plans they had for the Alliance (Iokibe 2016: 231). Tanaka's visit was to sought Nixon's blessing for Japan's normalizing relations with China, and Fukuda's visit was to build on expanding Tanaka's diplomatic initiative to reach out to China and expand it into an Asian wide initiative (Iokibe 2016: 232). Notwithstanding this, neither Tanaka nor his successor Prime Minister Miki undertook steps to expand Japan into a strategic power-as Japan's defense policy at that time was premised more upon détente and autonomous defenses whilst not seeking to become a military power (Shinkawa 2016: 194-195).

Japan's foreign policy took an increasingly "autonomous" streak during this decade. Prime Minister Fukuda Takeo had personal experience of the Tokyo Air Raids that that almost killed him during the Pacific War, and experienced the "unreasonableness" of the Occupation authorities whilst 
working at the Finance Ministry (Iokibe 2016: 217). Whilst growing up as an ardent nationalist, he deeply revered Prime Minister Kishi, and was particularly enamored with his ideas on Constitution revisionism and rearmament. He had recalled that it was important for Japan to "construct a political system that is completely free of reliance on the occupation forces", perceiving Yoshida and Ikeda served the Occupation authorities too much, and that it was wrong to have a Constitution not made by Japanese themselves and have relied on the Americans entirely for Japan's national defense (Iokibe 2016: 217). Yet, overtime Fukuda evolved, and even though he remained a nationalist, he also acquired an internationalist outlook, and had put in place the most forward looking foreign policy that Japan has seen in the postwar era. The Fukuda doctrine builds on what Tanaka has achieved with China, and undoubtedly the first-time postwar Japan expanded its diplomacy to focus on Southeast Asia. Fukuda's "Omni-directional foreign policy" should be seen as an attempt to reinforce the US-Japan relations as the cornerstone of Japanese foreign policy and use it as a base to further develop relations with Asia, and in Iokibe's words-this is not the "flipping of US to Asia" (Iokibe 2016: 232).

Over the course of the two and half decades, the US-Japan alliance has seen incremental changes to the power relations between the United States and Japan. By the 1970s, issues regarding burden sharing and allegations of Japan's free riding cropped up in Japan's bilateral relations with the US. Japan's rapid economic rise had made some in the United States question the degree of which Japan was shouldering the burden of defense arrangements. The United States not only demanded Tokyo to shoulder more of the cost of operations, but Japan had consistently refused to spend more than $1 \%$ of her GDP on defense. The United States also wanted Japan to participate in technology transfer arrangements. The United States under President Carter also wanted to ensure Japan did not get to repossess her own nuclear fuel (Iokibe 2016: 232). To that extent, Prime Minister Ohira Masayoshi and Suzuki Zenko took the traditional interpretation of the Constitution and the US-Japan Alliance, and by the beginning of the 1980s, the relationship of the US-Japan alliance was at a low.

Prime Minister Nakasone was arguably one of the more successful Prime Ministers in the postwar era. The US-Japan relations thrived during this period despite Japan was becoming economically richer and politically more powerful. With Japan's economic strength, he was able to steer Japan to greater heights in terms of her diplomacy in Asia and with the 
United States. He was also able to redeem Japan's image in the eyes of the South Koreans and the United States through cultivating close personal relations with not only President Reagan but also the South Korean leader Chun Doo-wan. Nakasone agreed to a technology transfer protocol with the United States, ignoring Japan's “Three Principles of Arms Exports". The Nakasone government interpreted that the transfer was legitimate because of the US-Japan Security Treaty, overrode the Cabinet Legislation Bureau and demanded that the defense budget be raised from $1 \%$ to $5 \%$ (Kusano 2016: 278).

During Nakasone's tenure, he increased trust between US and Japan, helped Japan establish a global presence and stepped up Japan's confrontation against the USSR after the drowning of the KAL Flight 007 (Kusano 2016: 278). The narrative debating the issues surrounding the US-Japan Alliance had changed remarkably in this decade. It reflected the changes in the capabilities, status and economic relationship that Japan had built over the last three decades, as well as the change in Asia-Pacific's security environment. Japan in the 1980s was a lot more confident and assertive than the Japan was in the 1950s and 1960s, and dealing with the United States from a position of strength, not weakness. Her relationship had in short morphed into one of "equal" at least from the Japanese point of view, as the asymmetricities that had so marked the relationship in the 1950s was now completely reversed, at least in the economic and technological spheres. This improvement brought on increased friction in the management of alliance matters as the alliance partners began wrestling over the question of the alliance cost, technology transfers and spillover effects from the tensions both countries faced in their bilateral relations.

Most interestingly, this period also coincided with a period of strong relationship with China at the same time. The 1980s is known today as a period of Gold Age for Sino-Japanese relations. This indicates that strong Japan-US and Japan-China relations can co-exist if conditions are right. As the USSR commits to Perestroika and Glasnost under Gorbachev, East Asia became a much more amicable place politically as relations between China, the USSR, the US and Japan improved, alleviating the tensions that the Cold War had instituted in the region over the past thirty years. This however did not last very long, as by the 1990s, Japan once again found herself at odds with her neighbors, particularly China over issues to do with history and other realpolitik concerns, creating a downward spiral in the bilateral relationship. These developments however had the important 
effect of reaffirming and boosting the US-Japan alliance to unprecedented heights, making their relations perhaps better than the decades before.

\section{Theme Three: Pacifism, the Use of Force and Global Engagement}

\section{The Fusion of Democracy and Pacifism}

It is debatable if democracy was an organic element in traditional Japanese political thinking and system as after all Taisho democracy and Freedom Rights Movement (自由民権運動 Jiȳ Minken Undō) are parts of recent Japanese history. What is not debatable however was the speed and ability of the Japanese to totally transform and adapt to democratic practices immediately after the Second World War, particularly if we consider democracy as an import that was hoisted upon the Japanese polity by the Americans.

Likewise, Pacifism as a belief was not organic prior to the Second World War as local conditions did not provide the incentives for people to embrace such a belief and there was no war from the start of Meiji which had significant popular movement opposing it (Yamamoto 2004: 2-5). There are however others who argue that Pacifism in Japan can be traced to earlier intellectual thinkers such as Kitamura Tokoku, Kinoshita Naoe, Uchimura Kanzo, Kotoku Shusui (Bamba and Howes 1978; Matsuzawa 2016) Admittedly, protests against the state in favor of peace is a modern postwar phenomenon. The onset of Pacifism in Japan during the late 1940s and 1950s therefore stemmed from a genuine desire of the Japanese people to consciously avoid war and bloodshed in the name of development and progress, and an attempt to prevent the ability of the State elites, whether the Cabinet Ministers or the Military from being able to mobilize the nation towards war time effort. The strength of pacifism in postwar Japan is therefore backed by the democratic will of the Japanese people to effectively marginalize (not eradicate) the remaining strands of right wing ultra-nationalism and conservatism residual in Japanese society in the postwar period.

This pacifism stems from institutions and practices introduced at a few levels. First and foremost, it draws its legal and political status from the Constitution, particularly Article 9 that renounces the option of War making as a sovereign right of the Japanese people to the way the Japanese elites interpreted the law. The Constitution is a conscious decision of the 
people, and in the words of John Dower, it is one of the most profound statements of apology that the Japanese people could make to her neighbors. The Constitution also rests the sovereignty of the nation in the name of the people, establishing the democratic institutions that make up contemporary Japan as we now know it. Second, the establishment of the US-Japan Alliance, and the implementation of the Yoshida doctrine removed the necessity of Japan as a sovereign country the need to upkeep an active military force when the responsibility for Japan's security was effectively outsourced to the Americans. Even as Japanese society eschewed militarism and war, the role of the military in Japan's control became one of the most important pillars of this pacifism. Third, the idea of peace is something that is deeply held by postwar generations as something they would practice as individuals. Japan's grassroots peace movements, usually made up of union or women groups, were often resisting the government, not so much because of defending personal moral belief than an collective act of advocacy calling on the government to oppose nuclear weapons and rearmament and not to sign partial peace or Japan-US treaties inimical to peace (Yamamoto 2004: 213-214). Peace and pro-Constitution activism stimulates the emergence of a new kind of citizenship, eradicating feudal remnants and promoting a new relationship between the state and the individual (Yamamoto 2004: 214). In short, pacifism had fused with democracy and the new Constitution and embedded deeply as important elements in Japanese national identity.

From Truman's "containment" policy to Eisenhower's "rollback Communism" initiative, the exigencies of the Cold War put United States at odds with the tendencies of Japanese politics. The American effort to remilitarize Japan was kept in check largely by a confluence of factors. First, the institutions that the United States imposed upon Japan by the Occupation authorities before Washington changed their mind i.e. the Constitution and the multi-party democratic system allowed the Japanese elites to use them to fend off American pressure to remilitarize. Second, the existence of principally the left-wing socialist movements and the nascent liberal democratic forces coincided the general mood among the civilians that made up much of the pacifist base - all add to the strength of the pacifist State. Third, the neo-realist nature of postwar politicians like Yoshida Shigeru who saw the Constitution and general public opinion as a shield to fend off US pressure and enable Japan's economy to recuperate. 


\section{The Subjugation of the Military}

One of the most revered and respected institutions in ancient and pre-war Japan is the military. As a political and social institution, the importance of the military's role in Japan cannot be overstated. Like many States in Asia, Japan has a praetorian culture in the sense that her Statesmen have always had linkages to the military-even the first generation of Meiji elites were samurais. By the end of the Pacific War, the status of the military had become drastically reduced, and the anti-militarism that had set in have perhaps for the first time in modern history completely negated any positive image of the military.

Postwar Japan had a clear and defined role mission for Japan's military - to stay hidden in plain sight. The idea of the military was different from that of other society have about their military. Japan's forces will be used only for self-defense, never for offensive capabilities. It would not have the right to come to the aide of her allies in any scenario for collective self-defense, and its deployment will be strictly for the defense of the Japanese homeland. The aversion to the use of military force in the postwar period was so strong that in 1958 Oe Kenzaburo (the 1994 Nobel Laureate) described those sitting for the JSDF entrance exam as the "shame of their generation" (Sado 2017). Overall the image of the military is one that is extremely negative, and is looked down upon by the politicians, journalists and civilian population.

To that extent, the idea of subsuming military to civilian control is a strange and new concept for Japanese people. There are two important strategies to ensure this is so. The first is for the control of the military was for the postwar authorities to completely oversee the military via civilian staff, second, was to ensure that the budget of the military is constrained and independently checked. Taken together the way the military is constituted and positioned within the Japan is that it is a force that remained "unseen" and is being relegated as "non-use" (Sado 2017: 205-208). Various veteran politicians such as Yoshida Shigeru, Fukuda Takeo and Ichiro Ozawa have on different occasions lamented on the importance of the role Japan could play in global affairs and spoke with regret on the inability of Japan to play a more global role with regards to United Nations affairs. Their responses were of course in hindsight natural given the exceptional rise of postwar Japan. Even as the Japanese subordinated the military to civilian control and disregarded the use of force, the institutionalization of democracy did not mean that Conservatism and rightwing nationalism disappeared from Japan. There was often an element of 
Conservatism and right wing nationalism that belied Japanese democracy. These two strands of ideological influences are conceptually different in nature, and will be explained later on in this chapter.

\section{Hiding in Plain Sight: Nationalists and Conservatives in Postwar Japan}

In the postwar period, even as Occupation authorities tried to eradicate or suppress all nationalist movements, they never completely disappeared. In particular, the ultra-nationalist groups with pre-war linkages had to survive by either disappearing into the rural areas or modifying their programs (Morris 1960: 160). For most part, nationalist parties across the spectrum did support the United States in their open narratives adopting a pro-US, anti-Soviet position (Shimbei Hanso), what they really wanted was for Japan to rearm and to adopt a more independent posture. As Morris put it, the "shimbei" [ support the US] for the nationalists is [preferable] to "Japan's present enfeebled condition, [and] the American alliance must be accepted as the lesser of two evils ......", and that nationalists regard that if they "sit back, they will fall prey to the Communist invasion; if [they] stand up, [they] will become the catspaw of American imperialism" (Morris 1960: 170). Nationalism is however not the sole domain of the political right, and left wing groups such as the Communists employed it too in Japan. The Japan Communist Party and the Social Party in the postwar era was only able to use nationalism to a limited effect in Japan, unlike the Chinese communist simply because in Japan, traditionally Japanese nationalism is being mobilized from reformist or revolutionary channels into that of national unity and military expansion which for all intents and purposes not useful for the Communists in Japan (Morris 1960: 399). Likewise for the extreme right in Japan, their weaknesses are: (1) nationalists are generally strong in critique, but lack concrete solutions; (2) they are reactionary politically but are unable to concrete material wealth and livelihood issues and (3) they are heavily clique-based, and rely heavily on the personalized ties with the leaders that have little mass appeal (Morris 1960: 402-403). Thus, Japan's political system has been locked in a struggle between liberals and conservatives, and from the extreme end, between the Communists and the Ultranationalists on the right. That being said, the right-wing (and also the Conservative) factions are far more in tune than the left wing will ever be in terms of its commensurability with traditional Japanese culture as well as with the employment of nationalism as a tool for statist political mobilization. This is 
particularly true of rural agrarian areas. Additionally, Conservatives are more likely to act in concert with rightwing groups than with Communist groups, and this is the reason why many tend to confuse Conservatives with Nationalists in Japan.

When the Occupational authorities changed their minds and began to ask the Japanese elites to reverse course and remilitarize because of the Cold War, they were met with resistance from groups across the political spectrum, particularly from the left wing and civic groups (Yamamoto 2004; Morris 1960: 386). The switch to move the emphasis from reform to stabilization, from democratization to anti-Communism only suited the Conservatives in Japan. The opposition to this was a strange coalition made up of leftists-socialist leaning politicians, grassroots activists and liberals.

The United States' preference for staunchly anti-Communist LDP conservatives to helm Japan of course is a conscious decision to ensure that Japan remains firmly in the United States orbit. Beyond the realization of the unpopularity of the American attempts to remilitarize Japan, Washington is also keenly aware of the popular sympathies the Japanese people have for leftist parties and ideology, even though they might not necessarily translate into support for the Soviet Union and China. The support for right of center Conservatives naturally however is to ensure that Japan remains firmly supportive of the United States and the alliance with her, as well as to prevent the USSR or China from making inroads into the domestic political process in Japan. Yet, ever so often, Japanese politicians, regardless of their political ideologies sought to resist the United States when they felt the policies of the United States were not advocating in the country's best interest. It explains why Yoshida, Hatoyama or Kishi (the former two never saw eye to eye) could interpret their own political choices and actions that put Japan's best interests first and foremost.

This however has an unintended consequence as the Liberal Democratic Party, housing the remnants of the pre-War cabinet politicians became very much the embodiment of US foreign policy in East Asia. The exigencies of the Cold War meant that Washington had not rehabilitated these pre-war politicians, but elevated them into positions of authority to foster illiberalism and revisionist views that American servicemen who have fought during the Second World War would neither recognize nor endorse (Overholt 2007). There is no contradiction here-as politicians world- 
wide would try and mold themselves into an image they imagine that would enable them to get the most votes.

There are of course differences between Conservatives in Japan and their nationalist counterparts even both largely use the reverence for the institution of the Emperor and pay homage to traditional Japanese culture to lay claim to the fact that their agendas and actions are inspired by the values of the Japanese nation. There are similarities between the groups as they are often skeptical of foreign influences, thus the Occupational authorities' plans for democratization, Constitutional constraints are in fact unwelcomed by both groups, so does the Chinese or Korean references to war issues. As Winkler notes (2011: 4-5), it is important to understand that there is a certain amount of ideological flexibility among the Conservatives in Japan, and the factionalism has helped to maintain the longevity of the Conservatives. There are important differences between the two groups. Right Wing groups consider that all people are equal before the Emperor, and thus they tend to side with the people, whilst Conservatives distrust the common man, and have little positive to say about egalitarianism unless it is the legal or spiritual kind. Despite these differences, right wing groups tend to side more with the Conservatives than other groups, including the left-wing groups who purport to be nationalist too.

\section{Pacifism and Spectator Democracy: Becoming Peace-Loving Global Citizens}

For average Japanese citizens, the struggle between the left leaning parties such as the Japan Socialist Party versus the Liberal Democratic Party, or the LDP elites versus the United States policy group or the politicians versus the bureaucrats, or citizenry versus the government has become somewhat of a normality in Japanese politics. This is seen as democracy at work-a democracy that has been imposed by the United States in the postwar period but has grown to be embraced by the Japanese people very quickly over a generation. Even though the US wanted to rearm Japan for the Cold War, pacifism quickly became entrenched in postwar Japan, as political doctrine, as an ideology and as a way of life and provided much resistance to prevent this from materializing.

In particular, pacifism became intertwined with the ideals of democracy - that every Japanese citizen to a large extent assimilated both pacifism and democracy that the two sets of ideas became conflated and 
subsumed in the beliefs and outlook of the average Japanese person: Japan was pacifist democracy; Japan did not and had no military-all they had was a small, defensive self-defense force and Tokyo followed the lead of the United States in all strategic matters. Japan and the Japanese people will never consider using force to resolve disputes or stake their interests. In short, pacifism has infused into Japanese national identity and influence almost all aspects of life and guided Japanese foreign and strategic perceptions as the influence of anti-militaristic norms was very real (Katzenstein 1996, 1998; Berger 1998, 2012). It had bearing on the way politics was conducted in Japan. For much of the postwar period, foreign policy issues and strategic direction were not dominant in domestic political campaigns, with the exception of US bases in Okinawa. The LDP's dominance was in part because voters wanted a party that will preserve "stability" in Japan, focused on economic reconstruction and prosperity. LDP's staunch support for the United States, and singlemindedness in preserving power and the capitalistic system made it the party of choice for both the Japanese people and the United States.

The dominance of the LDP however has led some to suggest that Japan was a "spectator democracy" that allowed Japanese citizens to watch world developments on the sidelines. This "non-participatory" mode also ensured that the central government is a father figure and that needed to be trusted and revered (Tominomori 1993: 83-84). This "paternalism" therefore forms the basis of government-people relations in Japan. Consequently even though there is a profession for egalitarianism among grassroots group, there is also a contradictory preference for hierarchy and elitism in Japanese politics. There is therefore an inherent tension between Conservatism and democracy (Winkler 2011: 6; Kitaoka 1992: 89-90), and this tension is most observed in the way Japanese talk and think about politics and foreign policy and the actual implementation. The result is a clear trend of hypocrisy in Japan's defensive posture.

This creates two different spheres of influences in Japan's public sphere-the pragmatic conservatives/nationalists who want Japan to rearm and attain a military that befits her economic clout, and ultranationalists who will deny any wrong doing in Japan's past (Yamamoto 2004: 216). The presence of the US-Japan forces negates Article 9, and casts doubts on Japan's pacifism. For the United States perspective, often it would look like that the Japanese were selfish in that they were not pulling their weight behind their own defense. From the perspective of Japan's neighbors, the pacifist democracy and the profession of " 3 Nuclear prin- 
ciples" on one hand and the existence of nuclear weapons hosted on US warships made Japan looked particularly hypocritical.

In the postwar period, Japan thus evolved into a democracy with certain special characteristics that provided the stability which both the Japanese people and Washington sought in the region. The first and most important facet is the dominance of the Liberal Democratic Party. The LDP currently led by Abe Shinzo came about as a merger of the Liberal Party led by Yoshida Shigeru and Democratic Party led by Hatoyama Ichiro in 1955. The LDP's longevity is unparalleled in East Asia, only to be outdone by the Communist Party of China and the Workers Party of Democratic People's Republic of Korea (DPRK). The LDP reign's was only briefly interrupted in 1993-1994 where two Socialist prime ministers (Hosakawa and Murayama) came to office.

The recipe for LDP's electoral success was simple: LDP politicians were effective in building pork-barrel relationships with their Constituents and other stakeholders. This included the powerful bureaucracy and close relationships with the multinational companies Zaibatsus. The LDP was also extremely adept at electoral manipulation, among other things the cooption of the agendas of the opposition and smaller parties (starting as early as during Hatoyama Ichiro's period where he co-opted the Socialist Parties agenda of normalizing relations with the Soviet Union). The LDP was also extremely creative in the implementation of the multi-seats district zones, effectively reducing the ability of smaller parties to organize and fight the campaign because of the constraints of their smaller sizes. The smaller interruption when LDP lost power in 1993-94 however allowed the Socialist party to address by reinstalling more single seat wards in the electoral process. Among the Japanese people, there is a constant fear any elevation of the leftist party would destroy the US-Japan Security Alliance and the good that the Japanese economy has done would be disrupted and Japan would become poor (Ogawa cited in Onishi 2005).

Japan's democracy was also for a large part marred by a weak civil society. Even though Japanese democracy is described as "vibrant" or "vigorous" by various commentators, the way civil society has developed remains lopsided. Despite the flourishing of private organizations in the fields of welfare or international aid, organizations that scrutinize government working and functions, human rights and other information still have little influence (Onishi 2005). This is not surprising, since many civil society organizations are still relying heavily on government funding, and this stands in consonance with the Japanese tradition that social organizations 
should exist for community solidarity and helping each other out so long they do not challenge the absolute feudal authority of the Tokugawa Shogunate (Pulsford et al. 2011).

For most part, Japanese electorate during the Cold War did not take the socialism very seriously simply because they were more worried about the possible destruction of the Japan-U.S. relations and that Japan would become poor (Oguma cited in Onishi 2005). This fear is not extraordinary-almost all the regimes in East Asia which were in the US led-bloc had seen authoritarian regimes holding onto power with varying degrees of similarity to the LDP during the Cold War. Chiang Kaishek's Kuomintang (KMT) in Taiwan, Lee Kwan Yew's People's Action Party (PAP) in Singapore and Park Chung Hee's Democratic Republican Party are all examples, although the United States has for a better part of the Cold War comfortable with an identifiable candidate in East Asia which is sympathetic to her causes (Hastings 1988: 32-34).

Thus, even though Japan's democratic progress vis-à-vis its Asian neighbors is admirable, Japan's pacifism is derived from a population dissuaded from socialism by fear of economic decline and maintained by a strong state whose Conservative politicians rely on a variety of nondemocratic means to keep the system going. As Japan's economy grew, and a new generation comes to the fore in Japan, the result is the emergence of a more confident generation devoid of war memories. This means the genuine sense of pacifism that has so motivated the postwar generation has been eroded increasingly. By the 1970s, the impetus for Japan to attain a political status commensurate with her political status is clear, and that Japan should indeed be allowed to contribute more to the United Nations. The Fukuda doctrine provided Japan with an Asian focus diplomatic focus, and by the 1980s, Japan has started for the first time to reconsider all the things that the nation has not undertaken previously. First, Japan began to utilize her economic influence to undertake Overseas Development Assistance to assert her political influence across China, Southeast Asia and elsewhere. Japan also became an increasingly influential contributor to the United Nations, requesting that she be made a permanent member of the UN Security Council as early as 1973. Nonetheless, it was only in 1992 that Japan joined the first peacekeeping UN Mission (Cambodia), signifying the reconsideration of a greater political and military role to come in the following decades. Japan also began to consider what sort of power it could evolve into by the 1980s as her economic prowess grew to a considerable degree. By the mid-1990s, Japan started considering to transform 
her military into a "post postmodern expeditionary army" (much like what the US Army has evolved during the War on Terror) (HunterChester 2016: 9, Chapter 8).

\section{The Erosion of Pacifism: Can Democracy and Historical Revisionism Co-Exist?}

The emergence of the neo-Conservatism in the post 1990 can only be explained by a coincidence of factors: the collapse of the USSR, the rise of China, the backlash against Japanese checkbook diplomacy exhibited in the first Gulf War and the general loss of strategic direction after the end of the Cold War. For the first few years of the decade, the strategic debate within Tokyo with regards to Japan's strategic direction was contemporaneous on the possible isolationism of the United States and the rise of China. Japan faced an increasing number of issues across all fronts with China ranging from PRC's nuclear test in 1995 and a dispute over the Senakaku/Diaoyu islands. As Japan began to debate the question of the utility of the US-Japan alliance domestically, a contemporaneous debate regarding the rise of the China threat was taking place. By 1996, President Clinton and Prime Minister Hashimoto agreed to reaffirm and reinvigorate the US-Japan alliance. The price of doubling down on the US-Japan alliance can only be done with popular support - that was the beginning of shift of public opinion against China contextualized against greater domestic and international reports regarding China's development. The 1998 DPRK missile tests that saw North Korean missiles overfly Japan (whom the North Korean says is a satellite test) provided Tokyo, particularly their neo-conservatives the perfect opportunity to advance their agenda. By supersizing the DPRK threat, the neo-Conservatives were able to rally the support for their agenda.

By Koizumi's tenure, the traditional way of conducting politics was undergoing a sea-change. Koizumi capitalized on the frustration of the voters who were concerned about the way traditional politics were conducted in Japan. Coming up in a political system where he did not have the prestige from a brand-name political family (like Abe Shinzo or Hatoyama Yukio), he was nonetheless singularly successful because he was able to do three things that were different from his predecessors. He was able to handle the bureaucracy by insisting on handpicking the liaison officers to the different ministries instead of relying on the Ministries' to send him the candidates. Koizumi had a very talented media advisor, Issao 
Nakajima who was able to sidestep the control of the traditional broadsheets by reaching out to the tabloids. Beyond that, there was also very careful usage of social media to help with the calibration of Koizumi's image and positions on issues. Koizumi was projected to be a leader of Japanese people, a force for change-whether it was confronting the Chinese, reforming Japan's postal system or vowing to "destroy" the traditional LDP by using female "assassins" to run against his political opponents. The visual politics portrayed him as a politician of strength, as a strong leader and a man of the people - and above all, someone who resist tyranny, power politics and corruption.

The success of Koizumi is also aided by his foreign policy success (or failure depending on one's perspective). First, Koizumi's September 2002 visit to DPRK was a tremendous success, when Kim Jong-il admitted "rogue elements" had abducted Japanese nationals in the past, and successfully having five abduction victims out of seventeen returned in May 2004. This however raised expectations of the Japanese people for the return of the rest of the abductees and for them to take a harder line against the DPRK. Second, US-Japan relations were amicable during his tenure, particularly because of Japan's support for the United States' War on Terror. Third, even though the United States was accused of "neglecting" Asia, resulting in the downward spiral of Sino-Japanese relations, an alternative interpretation is that the United States and Japan gained strategically in a big way during this period. By letting Japan "act" autonomously, it enhanced Japanese self-awareness of her security posture. Prime Minister Koizumi did not heed the calls of the Chinese and Koreans not to visit Yasukuni shrine. Acting defiantly, he visited the Shrine six times in his capacity as Prime Minister even as China and Korea, Singapore, Hong Kong, Taiwan and even Australia protested (Onishi 2006). One of Koizumi's advisors communicated to the author: "The Prime Minister believed that even if he had caved in to China and Korea on this matter [Yasukuni Shrine], they [China and Korea] still would not treat Japan with the respect she deserves ... it therefore did not matter what he did or did not do since no amount of reconciliation would get him [or Japan] any leeway with China or Korea". Instead, the protests from China and Korea boosted his popularity at home (except with the business community) and his ratings provided him with a political longevity that most of his LDP predecessors can only admire whilst at the same time help him with the political situation. 


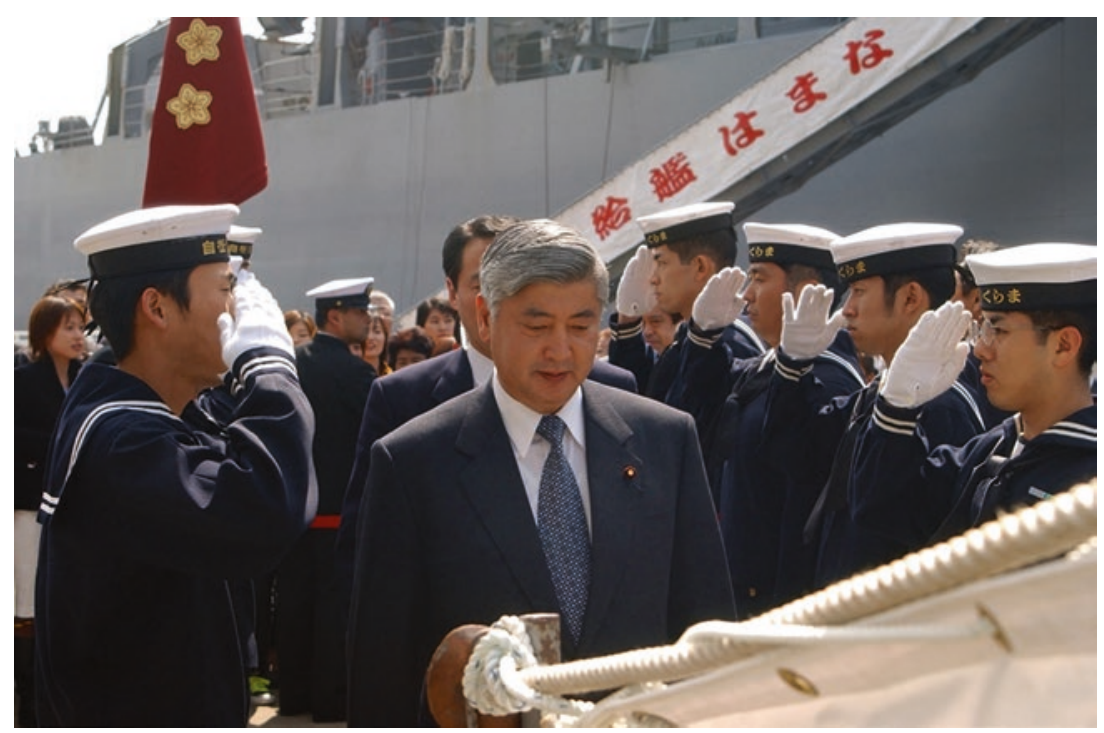

Photo: Mr. Nakatani, Director General of the Defense Agency, embarks on the Japan Maritime Self-Defense Force destroyer Kurama (DDH-144) during a homecoming reception of MSDF ships, Kirisame (DD-104), Kurama, and Hamana (AOE-424), March 16, 2002. Japan's MSDF have been in the Indian Ocean providing vital logistical support, including supplying fuel, to U.S. and coalition ships in the fight against terrorism. (By Jonathan R. Kulp, U.S. Navy [Public domain], via Wikimedia Commons)

Sino-Japanese relations had deteriorated to one of its lowest point in postwar history. There is however no question that by 2005 , neoconservatism had become a central element in Japanese politics, ending the dominance of pacifism as an ideology in Japanese society. Public opinion supported a tougher stance against China (Hoshino and Satoh 2012), and increasing cooperation with the United States. Even though a significant portion of electorate had doubts about the politicians' intent and capability, the surge of emotive nationalism became the basis of a true democratic force which Japanese harnessed against China. This provided Japan an opportunity to advance her strategic interests and give a big boost to the US-Japan alliance (Lai 2014). In this respect, Koizumi had managed to put forward the neo-Conservative agenda in a big way. The United States gained because by the end of Koizumi's tenure, many 
Chinese believe it might actually easier for US to handle Japan rather than do it by themselves. Like the Japanese, the Chinese too eased up on the US-Japan relations.

The support for this neo-conservative focus on security is not irrational nationalism. For the average laymen, whether the person lives in Tokyo, Hanoi or Manila, the rise of Chinese economic power and the reported irredentist agenda China is allegedly undertaking is usually enough to stoke a strong reaction. At the same time, this is often magnified by their own economic malaise and stagnation, accentuated by China's rise and the closing of the gap between their countries' comprehensive national strength. This of course is worsened by the fact that China is also set to overtake the United States as the World's largest economy in the near future, and represents a real chance that the United States might seek to drive a grand bargain with China by entering into a real comprehensive strategic partnership with the PRC. In other words, Japan faces the prospects of strategic abandonment which she has feared since the early 1970s (Frankel 1971; Schaller 1996). This double impetus therefore pushes Japan to undertake policies which would forestall or at least slow down the prospects of that happening as Japan seeks out a more independent and calibrated strategic policy.

Thus the erosion of pacifism in Japan is accompanied by a grim reality of grudging acceptance by the Japanese nation that it is time for Japan to undertake a greater sense of responsibility for her own defense as well as for global commitments worldwide (APH20C 2017). Japan's UN and international contributions will be discussed in depth in Chap. 4. Even as pacifism has imbued Japanese with a strong sense of liberalism and democracy, it is questionable if this has truly imbued deeply into the Japanese psyche. While Japanese people might have responded enthusiastically to universal concepts and ideals such as liberty, equality and human rights, their outlook imbued with fresh moral zeal, their moral compass did not extend much beyond the country's borders (Yoon cited in Yamamoto 2004: 219). Japan's quest for normalization and rejuvenation is therefore promising to change this.

By the time Abe Shinzo came to power in 2006, he laid the important ground work for the neo-conservative shift for Japan to play a greater part in her defense. The strategy was to hasten and build on the achievements of Hashimoto-Clinton agreement as well as the achievements under Koizumi-Bush on the US-Japan Alliance even as Japan tried to seek out a 
way to work with China. Abe's strategy lied in laying out the groundwork for greater public support for Japan's normalization and rejuvenation as a political power (Smith 2014, 2015; Tanaka 2017).

There are four central elements. First, Abe wanted to build a national education program to ensure that future generations of Japanese would have the "correct" historical understanding of events and feel "proud" of the country. This of course is aimed at negating the prevalence of the antimilitaristic norm that is so prevalent in the country and which Abe views as the fundamental barrier to Japan's normalization and rejuvenation. Linking this national education which in theory is supposed to transmit "traditional" culture, necessitates the definition of all things quintessentially "Japanese", and creates an in/out group dynamics that makes any criticism of this security policy look "unjapanese" and unpatriotic. The ideational concept of "face" is central to East Asian nationalism, and this element cannot be underestimated (Chien and Fitzgerald 2006). Second, given the Constitution is both a political and legal instrument, any attempt to reorient Japan's security posture would necessitate a legal maneuver. Abe has three sub-strategies to do incrementally erode the legal constraints and to pave the way for an eventual referendum on amending the Constitution. Taking his service as Koizumi's Chief Cabinet Secretary and as Prime Minister for the two separate terms, Abe Shinzo has: (i) increased the neo-conservative presence in the Diet, by coopting members, or forcing political opponents to adopt this policy orientation by persuasion, coercion or co-option; (ii) implemented gradual changes through administrative decrees and incremental legislation to continually erode the Constitutional constraints; (iii) using Prime Ministerial discretion to reinterpret and expand what is permissible under the US-Japan Alliance (such as the right to collective security). Third, since the early 2000, the Japanese government, including the DPJ governments of Hatoyama, Kan and Noda has tried to garner greater public support by highlighting through the media the dangers posed by the People's Republic of China and the Democratic People's Republic of Korea. In particular, they have sought to promote the wisdom of political moves to normalize the usage of force through the Japanese military. In short, the JSDF is now promoted as a force that can be deployed and used rather than one that should remain inconspicuous and not used. Since the March 11 disaster, the JSDF has become more accepted and been highly regarded in and outside of Japan. Fourth, the Japanese government has sought to raise the status of the 
JSDF and its actual fight capability by remedying its perceived inadequacies particularly in terms of how the JSDF is constrained and how it connects to the US forces in Japan and beyond.

\section{Neo-Conservatism and the Paradoxes of Japanese DEMOCRACY}

Conservatism, in its natural form are technically not antithetical with pacifism necessarily. The problem is that today, neo-Conservatism speaks to a trend that is deeply related to the belief that postwar institutions that had served Japan so well in the decades after the war is no longer a viable to meet the needs of Japan in the Post Cold War era. Neo-Conservatives therefore call for the overhaul if not removal of two of these institutionsthat of Pacifism and the Constitution. This means out of the three pillars that are being explored here: Constitution, US-Japan Alliance and Pacifism, the neo-Conservatives are asking to change the two of them. What can we make of the relationship between neo-conservatism and democracy, and of nationalism and pacifism?

To begin, it is important to distinguish between conservatism and neoconservatism in the Japanese context. The pre-dominant difference between today's neo-Conservative politicians from their predecessors during the Cold War is the neo-conservatives organizing principles and their evaluation of Japan's current responsibility for the Second World War, and Japan's position in East Asia vis-à-vis China and Korea and the general security environment. Neo-conservatives largely view that Japan should no longer have to continually bear responsibility for a war that is not waged by their generation. Further, Japan has made adequate apologies for contrition and that atoned for their wrongdoings by rendering help and aide to the countries that have been hurt by the misdeeds of the Japanese Imperial Army. This is a significant departure from those of their Conservative predecessors many who share a deferential attitude towards their neighbors, China and Korea because of the Pacific War. To that end, neo-Conservatives view that Japan's relations with either the Koreas and China are not special in any sense, particularly when their neighbors utilized "history" to put themselves on political and diplomatic moral high ground to extract political, economic and diplomatic concessions from Japan. A significant hallmark in neo-conservative is the way China is construed in their narratives. Their Conservative predecessors regard relations with China as friendly and hence do not constitute China as a security 
threat just as they regard South Korea's relations with Japan as a "special". Neo-conservatives in Japan, in their ideal form constitutes China as a security threat, and that even as the Republic of Korea is a common ally of the United States, Japan is not bound by any special relations with the Koreans. The neo-conservatives depart from their Conservative predecessors not only in terms of security outlook, relations with China and Korea and interpretations of war guilt, their also defer from their Conservative colleagues who have traditionally toed party-line factional politics.

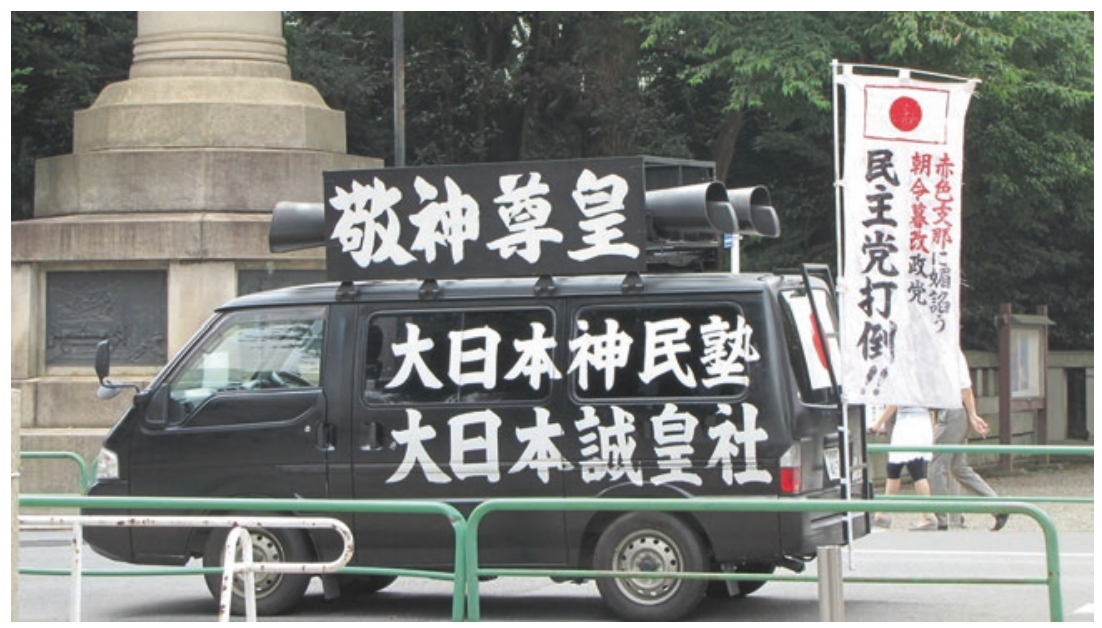

Plate: A Black Van Outside Yasukini Shrine advocating for the downfall of the DPJ in 2010

The neo-Conservatives have called on the Japanese nation to imbue future generations with a sense of pride. The act of renouncing war and the use of force is self-reflexive and suggests an act of contrite and penance. Right now, the neo-conservatives are asking young people in Japan to reorient her historical understanding, particularly among young people to ensure that they are not being shackled by the historical narratives and social memories associated with the War for a few reasons.

First, the politics of the postwar period privileged and sympathize with left wing tendencies, particular in their attitudes towards China and Russia. This goes against the grain of LDP political philosophy and thinking since its founding in 1955. Second, Conservatives regard the postwar narratives erode the current young people's sense of nationalism and belonging, 
providing a self-defeatist attitude. In short, foreigners outside of Japan as less than desirable forces within Japan are fostering the national historical narratives of Japan, and this undesirable trend must be stopped. Third, unless this sense of self-defeatism and self-critical reproach is removed to Japanese society at large, it would affect Japanese society and nation's ability to compete in East Asia politics. Fourth, repeated acknowledgement of this history would only place Japan in a position of servitude-not only in relation to the United States, but also to China and South Korea in particular. This puts Japan in an untenable position of having to surrender the moral high ground and kowtow to her neighbors politically and diplomatically. Fifth, despite the subservience and apologetic attitude Japan has shown towards China and Korea, there is no sign that the political pressure to extract concessions using history would stop. Consequently, there is even more incentive to foster a correct sense of history as cordial relations with China and Korea remain a distant dream. Six and most importantly, advocating the correct sense of history would help shore up support for the normalization and rejuvenation of Japan, in particular for Constitution revisionism and the US-Japan Security Treaty.

The Prime Minister is a well-known conservative with historical revisionist tendencies. The most important document to understand the character of Abe's historical revisionism is Abe's book Towards a Beautiful Country: My Vision for Japan published in 2006. For personal and intellectual reasons, Prime Minister Abe has been at the forefront to free Japan from these perceived shackles, and in Abe's own words, he seeks a "departure from the postwar regime" by "bringing back Japan" (Abe 2006 cited in Takahashi 2014).

While the publication of this book certainly provided much fuel for the Conservative moment, the tone and tenure of the Prime Ministers' remarks certainly raised concerns for Japan's closest neighbors. Conservative politicians making revisionist remarks or visiting the Yasukuni shrines are a familiar theme in Japanese politics and diplomatic relations for China and Japan, but the problem is that Prime Minister Abe seems deeply convinced by his beliefs and committed to realizing them. The irony is that criticisms from outside, particularly from China or Korea only serves to enrage ordinary Japanese, rally political support and further embolden these politicians.

Unlike other politicians (such as Koizumi who had excellent public image advisors), this Prime Minister's deeply held revisionism stems from deeply held personal convictions. First, the Prime Minister is of the view 
that his grandfather's conviction as a War Criminal is unfair and questionable. Second, the unfairness of having the Tribunal imposed sentences is like the Victor's justice, as convictions were based on concepts determined by Allied courts after the War and this in turn raises question about the legitimacy of the Tribunal. Third, the Prime Minister also has difficulty with the blame apportionment, questioning the mass media, society at large and implicitly the institution of the Emperor. Is it fair to really just put all the responsibilities on the convicted War criminals? (Takahashi 2014).

Taken together, Prime Minister Abe's new Conservatism has served as a rallying cry for all conservative groups, from grassroots to the national level. Whilst there is a view that there is a rightward shift in Japanese politics, particularly since the election of Prime Abe in 2012, is the electorate seeking "stability" and driven by a desire to forestall economic problems of the inexperience of the DPJ-nonetheless the election of Shinzo Abe puts the rightwing of Japan's political spectrum in office-where they have a rightful platform to articulate their visions and formulate policy (Hoffman 2018). There are alternate views of course, and the dissenting opinion is that Abe's election can be distilled down to the lack of viable and appealing opposition (Takahashi 2013; Nakano 2017) which is a main contributing factor. Regardless of this, not counting the years prior to the Koizumi administration, Prime Minister Abe Shinzo and his associates (PM Taro Aso etc.) have been near or at the echelons of Japan's political system since 2003 (when he became Secretary-General of the LDP) during Koizumi's tenure. At the same time, there is increasing recognition that neo-Conservatives have been stealthily mobilizing political movements at the grassroots level to popularize their agenda through organizations like Nippon Kaigi that grew from the merger of two organizations in 1997-Nibon Wo Mamoru Kokumin Kaigi [National Conference to Protect Japan] and Nihon wo Mamoru Kai [Association to Protect Japan] (Tawara 2017). Its stated mission on its website (www. nipponkaigi.org) is to suggest that it is a "civic group that presents policy proposals and promotes a national movement for restoring a beautiful Japan and building a proud nation". The most important goal for this organization is to amend the Constitution, and counts among its ranks influential members of Japanese society. Tawara notes that as at November 2015 , Nippon Kaigi accounted for $40 \%$ of the 717 Diet members in both houses of the Japanese parliament, and had help Abe mount the cabinets (Tawara 2017: 9). 
The neo-conservatives had therefore tended to do two things through Nippon Kaigi. First, there is a movement to promote "patriotic education" within Japan from 1990s. This is achieved through the writing of revisionist history textbooks written with this aim in mind (Rose 2006). The activities of Nippon Kaigi include promoting the revision of Constitution, adopting the textbooks published by Nibon Kyoiku Saisei Kiko [Japan Education Rebuilding Organisation] as well as the Society for History Textbook Reform. There are other practical acts such as pressuring school boards to display the Hinomaru national flag and sing the Kimiyago anthem during assemblies, and to monitor against left wing content taught in Schools (Tawara 2017: 13). The second is build a grassroot movement by increasing membership of local politicians (such as governors, mayors, assembly heads and mayors) in different prefectures into Nippon Kaigi. This idea is to grow a grassroots right-wing movement aimed to cultivate the next generation of Japanese youths to rightwing ideas and to neutralize counter arguments as being presented by the "left". In short, the Nippon Kaigi aims to promote a narrative that has been suppressed but never eradicated since the 1950s, and to operationalize the ideas by inviting politicians and legislators into its ranks. The view that Japanese politics has shift "rightwards" in mainstream International Politics might actually not be quite accurate, as the Conservatives (alongside the nationalists) has never quit talking about Constitutional amendments or taking a "correct" view of history since the 1950s. They just "blended in" for most part with the Japanese population and many kept their convictions.

Even though there is belief among analysts that the history textbook issue emerged in the mid-1980s, Ienaga Saburo's battles with the Conservative and nationalist forces over the approval of his history textbook began as early as the 1952. The talk about overturning the Constitution began as soon as the Constitution was enacted, at least this is true in the LDP in the 1950s. Thus, the neo-Conservatives sought to bring to the fore an agenda that existed early on in the postwar period, suppressed and subsided because of the shame and stigma that pacifism brought to bear. This has however been reversed recently with domestic changes in Japan that generational change brought and in the shifting dynamics in international affairs in the post Cold War world.

Japanese politics is now characterized by two paradoxes (McCormack 2008). First, the word "conservative" applies to those who need to remake and remodel Japan's postwar institutions, undertaking radical changes. 
Those who insist on "conserving" Japanese postwar democratic institutions are construed as "radicals" or "leftists". The second paradox is those who insist on subordination of Japanese interests to that of the United States describe themselves as "nationalists", while those who seek to prioritize Japanese over US interests are suspected of being "un-Japanese". McCormack argues this is nothing short of "Alice in Wonderland" confusion. Are we therefore to interpret that dominant ideology today in Japan is neo-conservatism with a nationalist twist in a democratic façade, and that pacifism is completely dead in the water? How do we reconcile with the success and longevity of nationalistic (Shintaro Ishihara or Hashimoto Toru) or Conservative leaders (Koizumi Junichiro or Abe Shinzo) as opposed to the politicians that truly advocate to listen to the people?

As in all fields that study human behavior, it is difficult to explain or predict Japanese politics here for certain. Yet, if there is one identity that most, if not all Japanese are proud of - it is the idea that Japan is a vibrant democracy. For all its imperfections, most Japanese people today are extremely proud of their democratic achievements.

Viewed from inside out, Japan's neo-conservatives calls for the nation to rally around the neoconservatives' idea of "values-based" foreign policy to defend against dictatorships (i.e. North Korea and the PRC) who are bent of asserting their will in the region both appeals to the democrat and the nationalist in the average Japanese. The neo-conservatives' articulation of a new Japan no longer troubled by issues concerned with the burden of history too resonates: why should successive generations of Japanese pay for their great-grandfathers' sins generations ago? As the neo-conservatism message resonated with those growing up during the postwar era, so did the nationalism and historical revisionism. At the same time, neoConservatives like Abe has never been shy to articulate that Japan is a democracy, and thus is "different" from China or Korea. The idea of "democracy" is therefore often used as a positive "value" that Japanese politicians sell their ideas (be it nationalism or neo-conservatism), but is also a reminiscent of the quest that Japanese people had across generations to seek out egalitarianism and excellence at the same time.

There are other possible explanations as well to the puzzle as to why nationalists and neo-conservatives are so popular in a democratic Japan. One convenient way is to view Japanese democracy in a new light: that Japan has never been truly a democratic country in the Western Liberal sense-particularly if democracy is defined in terms of party-turn over or the existence of a strong and well balanced civil society or the ability of 
citizens and local areas to change policy (think Okinawa) (McCormack and Norimatsu 2012).

There are some who might argue Japan's democracy is neither as wellestablished we often assume to be nor that democratic values are not as deeply ingrained in the electorate. In the words of one commentator, Japan became "democratic" in three months, soon after the Occupation Authorities system imposed the institutions on them. They never had to bleed for these democratic values, and certainly most figures that are enshrined as Yasukini Jinja did not die fighting for democracy (Leonard in Pyle 2007: viii-ix). The issue however is not whether they did or did not die fighting for democracy. The fact remains that for an entire generation, Japanese people have lived for pacifism and anti-militarism. As Japan never had much of a democratic tradition to begin with, the question as to why Japan became staunchly anti-militaristic in such a short time also deserves to be examined. For much of the postwar period, Japan's pacifist norm remained an important source of influence for much of the country's thinking. Since 1945, the Japanese nation made a conscious decision to disavow their right to use force. This disavowal of use of military force made the realization of Japan as a peace state entirely possible, and allowed Japan to build up not only her economic prowess, but also enable Japan to acquire an unprecedented amount of cultural capital, international respect and soft power (Vyas 2011). Thus today, many Japanese believe that pacifism and democracy are two sides of the same coin. Some believes that any attempt to erode pacifism is equivalent to eroding democracy, as Abe has learnt. The Japanese democracy is therefore facing unprecedented challenge. The best way to understand this is to view democracy as one of the competing ideological influences that is competing for the hearts and minds of the Japanese electorate.

Beyond ideas, the Japanese electorate prizes stability, pragmatism, traditionalism and cultural pride. In choosing their leaders, the Japanese people want these values, but on top of this they are often attracted to particular traits: strength and resistance-against great powers, against bullies against anything that Japanese feel that they do not stand for. They also value political brand names (hence the phenomenon of political dynasties in Japan). Thus, it is no surprise that the Japanese electorate would worship any politician who is able to articulate a romanticized notion of restoration and rejuvenation whilst using language that allude to tradition and democratic values at the same time (these two sets of values might not necessary match) as they address current concerns. Nakasone, Koizumi, Abe, Ishihara 
and Hashimoto are some who have projected the strongest and most appealing image in that sense (either through it is an image manipulation or pedigree) and who can persuasively convince the electorate that if elected, each (of them) will strongly articulate their interests, stimulate and preserve Japanese growth and restore Japanese tradition. These leaders are strongmen, not democrats, and ironically in a democratic Japan, they have the longest political longevity. These leaders will inevitably exhibit a strong leadership vis-à-vis other "strong" states in the international era (Satoh 2010), and guide Japan through the tempestuous waters of international politics and perilous economic times. In short, even if ordinary Japanese folks might be pacifists and democrats at heart, their perspective view of international politics is informed by hardcore realpolitik ideals that they believe only hardcore realists such as the neo-Conservatives or nationalist politicians can rise to the challenge.

At the same time, the same people who elect these strong leaders often do so out of a sense of propriety and fear-in particular fear of economic collapse. Thus at a critical juncture, the electorate often reach out to the party that oversaw postwar growth. The LDP provides this, simply because of her non-democratic methods to remain as the dominant party throughout the War. To that extent, the electorate can support contradictory policies even at the expense of their democratic values. Like Prime Minister Abe, the Japanese nation largely did not see a problem in Abe's articulation of the values-based diplomacy against the authoritarian China, Prime Minister reaching out to Vietnamese government (a Communist regime), to current Philippines President Duterte (a strongman who has little regard for human rights given his extra-judicial campaign at home), and to the Southeast Asian states like Myanmar or Malaysia and to Russia. Realpolitik, as opposed to democratic values drives these policies. These contradictory views need not be surprising. It is entirely possible for a country to preach and practice liberalism and democracy within her borders and practice realpolitik in her foreign relations with little regard for democratic values. Whether it is in Taisho Japan or the United States under George Bush, democracies can implement imperialistic or neo-imperialistic foreign policy. In today's Japan, as much as the Japanese pride themselves as a democracy, domestically, the rights of Okinawa residents are being sacrificed in the name of national security (McCormack and Norimatsu 2012; McCormack and Aritza 2017) Therefore, just because a country espouses to be a democracy, one should not automatically assume that her foreign policy will be infused with 
democratic values. In all fairness however, there strong democratic voices of clarity emanating from Japanese civil society to challenge all that Abe and the neo-Conservatives stand for. As Koichii Nakano at Sophia University says about "Japan is Great" boom: "The economy of Japan continues to be in recession, its per capita GDP has been overtaken by Korea ... The Abe government's repressive stance leading to repeated streamroller-voting in the Diet continues to undermine the dignity of the citizens. If we could become a nation that though about each and every person, we could put an end to the sobriquet 'Japan is great'" (Nakano cited in Shirana and Ikeda 2017: 5).

However, the Abe administration still faces a polity with deep seeded aversion to the State, the politicians and to the use of military force in general. As Oros notes (2017: 150), polling data has suggested that Japanese views of how to best provide for Japan's security has not been transformed by a more hostile environment. Even though the Japanese people recognize the challenges of a rising China and a belligerent DPRK (Hughes 2009; Landler 2018), they also recognize that the revision of the Constitution and the remilitarization of Japan [as encouraged by the United States (Shirana and Ikeda 2017: 1)] are detrimental to the values modern Japan holds dear. To that extent, even though reaffirming the US-Japan alliance might be the least offensive of the options they could take, the Japanese people have yet to figure out what is the best course of action to enhance their security both domestically and externally. This is to ensure that the achievements of postwar generation and the way of life of modern Japan are not sacrificed in the name of national security, and that Japan would continue its resurgence as a great nation and a responsible member of the international community in time to come. As Satoh (2010:586) argues, we might now be seeing the clearest signs that democratic participation is replacing quiescent citizen obedience in Japan. At the same time, the desire for Japan to be a responsible member of the international community is providing resistance to the assertive state nationalist project that is currently underway. There is no question that Japan's democratic resilience will continue to moderate the excesses of the Japanese government for the foreseeable future.

\section{REFERENCES}

Advisory Panel on the History of the 20th Century and on Japan's Role and the World Order in the 21st Century [APH20C], (Translated by Tara Cannon), Toward the Abe Statement on the 70th Anniversary of the End of World War II, (originally published as Sengo 70 nen danwa no ronten by Nikkei Publishing Inc, 2015), Tokyo: Japan Publishing Industry Foundation for Culture, 2017. 
Bamba, N., \& Howes, J.F. Pacifism in Japan: The Christian and Socialist Tradition. Vancouver: University of British Columbia Press, 1978.

Berger, T. Cultures of Antimilitarism: National Security in Germany and Japan. Baltimore, MD: Johns Hopkins University Press, 1998.

Berger, T. War, Guilt and World Politics. Cambridge: Cambridge University Press, 2012.

Blacker, C. The Japanese Enlightenment: A Study of the Writings of Fukuzawa Yukichi. Cambridge: University of Cambridge Press, 1964.

Brownlee, J.S. translated. "The Jeweled Comb-Box: Motoori Norinaga's Tamakushige." Monumenta Nipponica vol. 43, no.1, 1988, 45-61.

Catalinac A.L. "From Pork to Policy: The Rise of Programmatic Campaigning in Japanese Elections" The Journal of Politics. 2015;78 (1):1-18.

Chen-Weiss, Jessica. Powerful Patriots: Nationalist Protest in China's Foreign Relations. Oxford and New York: Oxford University Press, 2014.

Chien, S., \& Fitzgerald, J. The Dignity of Nations: Equality, Competition and Honor in East Asian Nationalism. Hong Kong: The University of Hong Kong Press, 2006.

Dian, M. The Evolution of the US-Japan Alliance: The Eagle and the Chrysanthemum. Oxford: Chandos Publishing 2014.

Dower, J. Empire and Aftermath: Yoshida Shigeru and the Japanese Experience, 1878-1954. Cambridge: Harvard University Press, 1979 \& 1988.

Faiola, A. "In Japan, the Lipstick Ninjas Get Out the Vote." The Washington Post, 3 September 2005.

Frankel, M. "Japan Inc." and "Nixon Shocks." The New York Times, Nov 251971.

Fukui, H. Party in power: the Japanese Liberal-Democrats and policy-making. Canberra: Australian National University Press, 1970, https://openresearchrepository.anu.edu.au/handle/1885/115041

Fukuzawa, Y. (1875). An Outline of a Theory of Civilization, (Retranslation based on the 1969 Keio Japanese version) David Dilworth \& Cameron Hurst, New York: Columbia University Press, 2008.

Fukuzawa, Y. Autobiography of Yukichi Fukuzawa, (Revised Translation by Eiichi Kiyooka), New York: Columbia University Press, 2007 Edition.

Funabashi, Y. "New Centrist Conservatism", The Japan Times, 15 January 2016. https://www.japantimes.co.jp/opinion/2016/01/15/commentary/japancommentary/new-centrist-conservatism/

Green, M. Arming Japan: Defense Production, Alliance Politics, and the Postwar Search for Autonomy. New York: Columbia University Press, 1995.

Hamano, S.B. "Incomplete Revolutions and Not so Alien Transplants: The Japanese Constitution and Human Rights." Journal of Constitutional Law, University of Pennsylvania, vol. 3, no. 1, pp 415-490.

Hastings, M. The Korean War. London, Simon and Schuster, 1988.

Hoey, F. Sato, America and the Cold War: US-Japanese Relations 1964-1972. New York and London, Palgrave Macmillan, 2015. 
Hoffman, R. "Why Steve Bannon Admires Japan", The Diplomat, 22 June 2018.

Hoppens, R. The China Problem in Postwar Japan: Japanese National Identity and Sino-Japanese Relations. London: Bloomsbury, 2015.

Hoshino, T., \& Satoh, H. Through the Looking Glass? China's Rise as Seen from Japan, Journal of Asian Public Policy, 2012, Vol. 5, No. 2: 181-198.

Hughes, C.W. Japan's Remilitarisation. London, Routledge for International Institute for Strategic Studies, 2009.

Hunter-Chester, David. Creating Japan's Ground Self-Defense Force: A Sword Well Made, 1945-2015, London: Rowman and Littlefield (Lexington Books), 2016. Iokibe, M. "Fukuda Takeo: Winner in Policy, Loser in Politics" in Watanabe, A. (ed). The Prime Ministers of Postwar Japan 1945-1995: Their Lives and Their Times, (Translated by Robert D. Eldridge), London: Rowman and Littlefield (Lexington Books), 2016.

Johnson, C. "The 1955 System and the American Connection: A Bibliographic Introduction." JPRI Working Paper No. 11, July 1995, http://www.jpri.org/ publications/workingpapers/wpl l.html

Kantei Japan. "General Policy Speech by Prime Minister Junichiro Koizumi to the 156th Session of the Diet", 31 Jan 2003, https://japan.kantei.go.jp/ koizumispeech/2003/01/31sisei_e.html

Katsube, Seigyi. Sento zuihitsu (ca 1785-88) In vol. 6 of Zuibitsu hyakkaen, ed. Mori Senzo et al. Chuo Koronsha, 1983.

Katzenstein, P. Cultural Norms and National Security: Police and Military in Post War Japan. Ithaca: 1998.

Katzenstein, P. The Culture of National Security. Columbia University Press, 1996.

Kissinger, H. The White House Years. Boston: Little, Brown and Co. Book Club, 1979.

Kissinger, H. Years of Upheaval. Boston: Little Brown and Co. 1982.

Kitaoka, S., "Kishi Nobusuke: Frustrated Ambition" in Watanabe, A. (ed). The Prime Ministers of Postwar Japan 1945-1995: Their Lives and Their Times, (Translated by Robert D. Eldridge), London: Rowman and Littlefield (Lexington Books), 2016.

Kitaoka, I. Nihon Honshu Shugi. Tokyo: Ocha Nomizu Shubo, 1992.

Koga, Y. Inheritance of Loss: China, Japan, and the Political Economy of Redemption after Empire (Studies of the Weatherhead East Asian Institute) University of Chicago Press; 1 edition (November 28, 2016).

Kosaka, M. "Sato Eisaku: The Truth about the Politics of Waiting" in Watanabe, A. (ed). The Prime Ministers of Postwar Japan 1945-1995: Their Lives and Their Times, (Translated by Robert D. Eldridge), London: Rowman and Littlefield (Lexington Books), 2016.

Kupchan, C. How Enemies Become Friends: The Sources of Stable Peace. Princeton and Oxford: CFR-Princeton University Press, 2010. 
Kusano, A. "Nakasone Yasuhiro: The Appearance of a Presidential Prime Minister" in Watanabe, A. (ed). The Prime Ministers of Postwar Japan 1945-1995: Their Lives and Their Times, (Translated by Robert D. Eldridge), London: Rowman and Littlefield (Lexington Books), 2016.

Lai, Y.M. Nationalism and Power Politics in Japan's Relations with China: A Neoclassical Realist Interpretation, Oxford and New York: Routledge, 2014.

Landler, M. "North Korea Asks for Direct Nuclear Talks, and Trump Agrees." The New York Times, 8 March 2018.

Leung, P.E. "China's Quasi-War with Japan: The Dispute Over the Ryukyu (LiuChiu) Islands", 1871, UC Santa Barbara, 1978 available at Proquest Dissertation database.

Mark, C. The Abe Restoration. Maryland: Rowan and Littlefield, 2016.

Maruyama, M. Studies in the Intellectual History of Tokugawa Japan (1975), New Jersey: Princeton University Press (Paper pack Reprint 2014).

Matsuzawa, Y. Dreams and Frustration of Liberal Democratic Movement, Tokyo: Iwanami Shoten, 2016 [松沢 裕作, 自由民権運動〈デモクラシー〉の夢と挫折, 岩波書店, 2016].

McCormack, G. Client State: Japan in the American Embrace. London and New York: Verso, 2007.

McCormack, G. "Conservatism" and "Nationalism". The Asia-Pacific Journal: Japan Focus, in The Puzzle, vol. 6, no. 6, 2008, https://apjjf.org/-GavanMcCormack/2786/article.pdf

McCormack, G., \& Aritza, S. The Japanese State Versus the People of Okinawa: Rolling Arrests and Prolonged and Punitive Detention, The Asia-Pacific Journal: Japan Focus, Vol. 15, Issue 2, No. 4, Jan 2017.

McCormack, G., \& Norimatsu, S.O. Resistant Islands: Okinawa Confronts Japan and the United States. Maryland: Rowman and Littlefield Publishers, 2012.

Middlebrooks, W. Beyond Pacifism: Why Japan must become a "Normal" Nation. Praeger: Connecticut and London, 2008.

Morris, I. Nationalism and the Right Wing in Japan: A Study of Post War Trends. London and New York: Oxford University Press, 1960.

Mulgan, A.G. Ozawa Ichiro and Japanese Politics: Old Versus New. Oxford and New York: Routledge, 2015.

Nagai, K \& Toshitani, N, eds. Shiryo Nihonkoku Kenpo (Document: The Constitution of Japan) Vol. 2 and 3 (Tokyo: Sanseido) 1986. 永井憲一、利谷信義編『資料 日本国憲法2·3』(三省堂、1986).

Nakamura, M. Shoburon (1843), In Vol. 6 of Bushido Zensho, ed., Inoue Tetsujiro, Saeki Ariyoshi, Ueki Naoichiro, and Kokusho Kankokai, 1998.

Nakano, K. "The Death of Liberalism in Japan", The New York Times, 15 Oct 2017, https://www.nytimes.com/2017/10/15/opinion/liberalism-japanelection.html

O'Dwyer, E. Significant Soil: Settler Colonialism and Japan's Urban Empire in Manchuria, Harvard University Asia Center, 2015. 
Onishi, N. "Why Japan Seems to be Content to Be Run by One Party", The New York Times, Sep 7, 2005, https://www.nytimes.com/2005/09/07/ world/asia/why-japan-seems-content-to-be-run-by-one-party.html

Onishi, N. "Koizumi Exits Office as He Arrived: Defiant on War Shrine." The New York Times August 16, 2006, https://www.nytimes.com/2006/08/16/ world/asia/l6japan.html

Oros, A. Japan's Security Renaissance: New Policies and Politics for the Twenty-First Century. New York: Columbia University Press, 2017.

Overholt, W. Asia, America and the Transformation of Geopolitics, Cambridge: Cambridge University Press, 2007.

Ozawa, I \& Gower, E. eds, Blueprint for a New Japan: The Rethinking of a Nation. Tokyo: Kodansha, 1994.

Paine, S.C.M. The Japanese Empire: Grand Strategy from Meiji Restoration to the Pacific War. Cambridge: Cambridge University Press, 2017.

Park, C.H. "Conservative Conceptions of Japan as a "Normal Country: Comparing Ozawa, Nakasone and Ishihara" in Soeya, Y., Tadakoro, M. \& Welch, D.A., Japan as "Normal Country"? A Nation in Search of its Place in the world. Toronto: University of Toronto Press, 2011.

Pyle, K. Japan Rising: The Resurgence of Japanese Power and Purpose. New York: Public Affairs Perseus Books Group, 2007.

Richardson, B. Political Culture of Japan, Berkeley, UC Press, 1974.

Rousseau, D. Identifying Threats and Threatening Identities: The Social Construction of Realism and Liberalism. California: Stanford University Press, 2006.

Rose, C. "The Battle for Hearts and Minds: Patriotic Education in Japan in the 1990s and Beyond" in Shimazu, N., Nationalisms in Japan, Oxford and New York, 2006.

Pulsford, A., Bhattarai, N., \& Shibuya, H. "March 11 disasters a turning point for Japanese civil Society." The Japan Times, Sep 15, 2011.

Sado, A. The Self Defense Forces and Postwar Politics (First published in 2006 and translated by Noda Makito), Tokyo: Japan Publishing Industry Foundation for Culture (JPIC), 2017.

Sakamoto, K. "Visits to Yasukuni Shrine by the Prime Minister and Japan-China Relations: What is Confusing about the Debate?", published in [阪大法学] The Law Association of Osaka University, Vol. 64, No. 3,4, 2014, https://www. jiia-jic.jp/en/resourcelibrary/pdf/Sakamoto_Visits_to_Yasukuni_Shrine_by_ the_Prime_Minister_and_Japan-China_Relations_What_is_Confusing_the_ Debate.pdf

Samuels, R. “Japan's Shifting Strategic Discourse, Sigur Center for Asian Studies Policy Brief", Jan 2013, pp 1-6, http://www.risingpowersinitiative.org/wpcontent/uploads/policybrief_jan2013_japan.pdf 
Samuels, R.J. "Rich Nation, Strong Army": National Security and the Technological Transformation of Japan. Ithaca, NY: Cornell University Press, 1994.

Satoh, H. Legitimacy Deficit in Japan: The Road to True Popular Sovereignty, Politics and Policy, Vol. 38, No. 3, 2010, pp 571-588.

Schaller, M. America's Favorite War Criminal: Kishi Nobusuke and the Transformation of U.S.-Japan Relations. JPRI Working Paper No. 11, July 1995, http://www.jpri.org/publications/workingpapers/wpl l.html

Schaller, M. "The Nixon Shocks and US-Japan Strategy Relations (1969-74)", The University of Arizona, Working Paper No. 2, 1996 https://nsarchive2. gwu.edu/japan/schaller.htm

Schneider, E. Democracy without Competition in Japan. New York, Cambridge University Press, 2006.

Shimazu, N. Nationalisms in Japan. Oxford and New York, 2006.

Shinkawa, T., Miki Takeo: Politics of Conviction and Public Opinion in Watanabe, A. (ed). The Prime Ministers of Postwar Japan 1945-1995: Their Lives and Their Times, (Translated by Robert D. Eldridge), London: Rowman and Littlefield (Lexington Books), 2016.

Shirana, M., \& Ikeda, T. (introduction by Nakano K.). "Japan is Great", The AsiaPacific Journal: Japan Focus, Vol. 15, Issue 3, Feb 2017.

Smith, Sheila A. Japan's New Politics and the U.S.-Japan Alliance. Washington D.C.: Council for Foreign Relations, 2014.

Smith, S. Intimate Rivals: Japanese Domestic Politics and a Rising China. New York: CPR-Columbia University Press Book, 2015.

Soeya, Y. "A Normal Middle Power: Interpreting Changes in Japanese Security Policy in the 1990s and After" in Soeya, Y., Tadakoro, M. \& Welch, D.A., Japan as "Normal Country"? A Nation in Search of its Place in the world. Toronto: University of Toronto Press, 2011.

Soeya, Y., Tadakoro, M., \& Welch, D.A., Japan as "Normal Country"? A Nation in Search of its Place in the world. Toronto: University of Toronto Press, 2011.

Strom, Stephanie. "Japan's Ultimate Insider: The Premier's Secretary." The New York Times, 26 June 2001, https://www.nytimes.com/2001/06/26/ world/japan-s-ultimate-insider-the-premier-s-secretary.html

Tamanoi, M.A. 2009 Memory Maps: The State and Manchuria in Postwar Japan. Honolulu: University of Hawaii Press.

Tanaka, A. (translated by Hoff, J.C.). Japan in Asia: Post Cold War Diplomacy, (first published 2007 in Japanese), Tokyo: Japan Publishing Industry Foundation for Culture (JPIC), 2017.

Tanaka, A. "Why has the LDP Stayed in Power so Long in Post-War Japan?: Democratic System Support and Electoral Behavior." UC Irvine Centre for the Study of Democracy Working Paper, 2007, https://escholarship.org/uc/ item $/ 5 \mathrm{gm} 0 \mathrm{f} 2 \mathrm{jf}$ 
Takahashi, T. “Abe’s Campaign to revise Japan’s Constitution”, East Asia Forum, 15 June 2013, http://www.eastasiaforum.org/2013/06/15/abes-campaignto-revise-japans-constitution/

Takahashi, T. "Japanese Neo-Conservatism: Coping with China and North Korea”, Security Challenges. Vol. 6, No.3 (Spring 2010) pp 21-40.

Takahashi, T. "The National Politics of Yasukuni Shrine in Shimazu, N., Nationalisms in Japan, Oxford and New York, 2006.

Takahashi, T. "Why Abe is pushing for the right to collective self-defence", East Asia Forum, 20 June 2014, http://www.eastasiaforum.org/2014/06/20/ why-abe-is-pushing-for-the-right-to-collective-self-defence/\#more-42220

Tawara, Y. What is the Aim of Nippon Kaigi, the Ultra-Right Organization that Supports Japan's Abe Administration ?”, The Asia-Pacific Journal: Japan Focus, Vol. 15, No.1 1st Nov 2017.

Taylor, A. "Japan in the 1950s." The Atlantic, 12 March 2014, https://www. theatlantic.com/photo/2014/03/japan-in-the-1950s/100697/

Tominomori, E. Nihongata Minshuhugi no Kozu. Tokyo: ND Books, 1993.

Vosse, W., Drifte, R., \& Blechinger-Talcott, V. Governing Insecurity in Japan: The Domestic Discourse and Policy Response. Oxford and New York: Routledge, 2017.

Vyas, U. Soft Power in Japan-China Relations: State, sub-state and non-state relations. Oxford and New York: Routledge, 2011.

Watanabe, H. A History of Japanese Political Thought, 1600-1901. Translated by David Noble. LTCB International Library Trust, International House of Japan, 2012.

Watanabe, A. (ed). The Prime Ministers of Postwar Japan 1945-1995: Their Lives and Their Times, (Translated by Robert D. Eldridge), London: Rowman and Littlefield (Lexington Books), 2016.

Will, G.F. "The Legacy of Japan's Lion Heart.” The Washington Post, 24 August 2006, https://www.washingtonpost.com/archive/opinions/2006/08/24/ the - legacy-of-japans-lion-heart/ 5562 dba $3-04$ ee - 47 e 9 - b ba 8 7caa8402a393/?utm_term=.30e665c9206d

Winter, M. Abe and the Bureaucracy: Tightening the Reins, The Diplomat, 16 June 2016, https://thediplomat.com/2016/06/abe-and-the-bureacracytightening-the-reins /

Winkler, C. The Quest for Japan's New Constitution: An Analysis of Visions and Constitutional Reform Proposals. 1980-2009, Oxford and New York: Routledge, 2011.

Yomiuri Shimbun Political News Department. (Translated by John Rossman). Perspectives on Sino-Japanese Diplomatic Relations, Tokyo: Japan Publishing Industry Foundation for Culture (JPIC), 2017.

Yuasa, Jozan. Bunkai zakki (n.d.) In Nihon zuibitsu taisei, (ed) Nihon Zuihitsu Taisei Henshubu, first series, vol. 14, Yoshikawa Kokunkan, 1993. 
Yoshida, S. (Ed by Hiroshi Nara). Yoshida Shigeru: Last Meiji Man (Translated from Japanese Edition in 1961). Plymouth: Roman and Littlefield, 2007.

Yamamoto, M. Grassroots Pacifism in Post-War Japan. Oxford and New York: Routledge Curzon, 2004.

孫崎 享, 戦後史の正体 (「戦後再発見」双書 1 ) 単行本, 東京,創元社, 2012.

Open Access This chapter is licensed under the terms of the Creative Commons Attribution 4.0 International License (http://creativecommons.org/licenses/ by $/ 4.0 /$ ), which permits use, sharing, adaptation, distribution and reproduction in any medium or format, as long as you give appropriate credit to the original author(s) and the source, provide a link to the Creative Commons licence and indicate if changes were made.

The images or other third party material in this chapter are included in the chapter's Creative Commons licence, unless indicated otherwise in a credit line to the material. If material is not included in the chapter's Creative Commons licence and your intended use is not permitted by statutory regulation or exceeds the permitted use, you will need to obtain permission directly from the copyright holder.

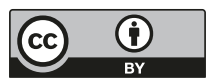

